Article

\title{
A Supercritical $\mathrm{CO}_{2}$ Waste Heat Recovery System Design for a Diesel Generator for Nuclear Power Plant Application
}

\author{
Jin Ki Ham ${ }^{1,2}$, Min Seok Kim ${ }^{2}$, Bong Seong Oh ${ }^{1}$, Seongmin Son ${ }^{1}$, Jekyoung Lee ${ }^{2}$ and \\ Jeong Ik Lee ${ }^{1, *}$ \\ 1 Department of Nuclear and Quantum Engineering, Korea Advanced Institute of Science and Technology, \\ 373-1 Guseong-dong Yuseong-gu, Daejeon 34141, Korea; jkham@kaist.ac.kr (J.K.H.); \\ bongseongoh@kaist.ac.kr (B.S.O.); ssm9725@kaist.ac.kr (S.S.) \\ 2 Korea Shipbuilding \& Offshore Engineering, 75 Yulgok-ro, Jongno-gu, Seoul 03058, Korea; \\ minseok.kim@ksoe.co.kr (M.S.K.); jekyoung.lee@ksoe.co.kr (J.L.) \\ * Correspondence: jeongiklee@kaist.ac.kr; Tel.: +82-42-350-3829; Fax: +82-42-350-3810
}

Received: 13 November 2019; Accepted: 5 December 2019; Published: 9 December 2019

check for updates

\begin{abstract}
After the Fukushima accident, the importance of an emergency power supply for a nuclear power plant has been emphasized more. In order to maximize the performance of the existing emergency power source in operating nuclear power plants, adding a waste heat recovery system for the emergency power source is suggested for the first time in this study. In order to explore the possibility of the idea, a comparison of six supercritical carbon dioxide $\left(\mathrm{S}-\mathrm{CO}_{2}\right)$ power cycle layouts recovering waste heat from a 7.2 MW alternate alternating current diesel generator (AAC DG) is first presented. The diesel engine can supply two heat sources to the waste heat recovery system: one from exhaust gas and the other from scavenged air. Moreover, a sensitivity study of the cycles for different design parameters is performed, and the thermodynamic performances of the various cycles were evaluated. The main components, including turbomachinery and heat exchangers, are designed with in-house codes which have been validated with experiment data. Based on the designed cycle and components, the bottoming S- $\mathrm{CO}_{2}$ cycle performance under part load operating condition of AAC DG is analyzed by using a quasi-steady state cycle analysis method. It was found that a partial heating cycle has relatively higher net produced work while enjoying the benefit of a simple layout and smaller number of components. This study also revealed that further waste heat can be recovered by adjusting the flow split merging point of the partial heating cycle.
\end{abstract}

Keywords: emergency diesel generator; supercritical carbon dioxide cycle; waste heat recovery system; bottoming cycle

\section{Introduction}

The earthquake that occurred in Japan on 11 March 2011 induced a tsunami with several waves whose height reached more than ten meters. Unfortunately, the Fukushima Daiichi nuclear power plant could not maintain its integrity after the large earthquake and tsunami. One of the major reasons was that the electric power supply lines to the site as well as the operational and safety infrastructure on the site were severely damaged. As a result, the on-site and off-site electrical power loss led to the loss of the cooling function in three reactor units and the spent fuel storage pools. Despite of the follow-up efforts at the Fukushima Daiichi nuclear power plant staff, the reactor buildings in Units 1 , 3 and 4 were breached due to a hydrogen explosion [1]. 
After the Fukushima accident, various countries operating nuclear power plants have revised their policies while adding more safety systems. In Korea, 50 short and long-term action items were identified and implemented to respond to the post-Fukushima accident nuclear safety concerns. Among these items, access to a vehicle with generators and batteries is a key lesson from the long term complete Station Black Out (SBO) accident that led to the core melting of the Fukushima nuclear power plant [1]. Table 1 shows some of the improvements implemented after the Fukushima accident.

Table 1. Safety improvements after the Fukushima accident (recreation of the figure in Ref. [1]).

\begin{tabular}{|c|c|c|}
\hline & Current Status & Improvements \\
\hline Electric Power System & $\begin{array}{l}\text { *2 EDGs/unit } \\
\text { - Loss of offsite power } \\
* 1 \text { AAC DG/2 or } 4 \text { units } \\
\text { - Loss of cooling function (SBO) }\end{array}$ & $\begin{array}{l}{ }^{*} \text { Movable vehicle } \\
\text { for generator and batteries } \\
-\sim 2014, \text { All NPPs }\end{array}$ \\
\hline Cooling System & $\begin{array}{l}\text { * Redundancy ( } 2 \text { trains) } \\
* \text { SFP has multiple sources }\end{array}$ & $\begin{array}{l}\text { * Prepare supplementary methods } \\
\text { - fire truck, etc. } \\
\text { - 2013, All NPPs }\end{array}$ \\
\hline Fire Protection System & $\begin{array}{l}\text { * Fire hazards analysis/10 years } \\
\text { * Fire protection plans }\end{array}$ & $\begin{array}{l}\text { * Improving the firefighting plan } \\
\text { * Improving fire protection facility } \\
-\sim 2015 \text {, All NPPs }\end{array}$ \\
\hline
\end{tabular}

Even though these safety actions are new suggestions adopted in operating nuclear power plants, improving nuclear safety has always been emphasized, even before Fukushima accident. Hence, in this study, an additional power supply system without substantially revising the layout and systems of an existing nuclear power plant will be proposed.

Currently, Korean nuclear power plants have two emergency diesel generators (EDG) and a non-class 1E diesel generator for each unit. Furthermore, an alternate alternating current diesel generator (AAC DG) for the emergency power supply that can be used for multiple on site units is installed. AAC DG is a standby system to supply the emergency power to the nuclear power plant when both EDGs are unavailable during accident conditions. However, AAC DG only provides emergency electrical power to the class $1 \mathrm{E}$ safety system due to its limited rated power and fuel tank size. Thus, if the AAC DG can generate more power without revising current layout of a nuclear system, the additional power can be used for further improving the nuclear safety. The proposed idea to fulfill this mission is adopting a waste heat recovery system to generate electricity further. The waste heat is generated from AAC DG. Figure 1 shows the configuration of the schematic emergency power supply system of the nuclear power plant.

The target nuclear power plant to apply a waste heat recovery system is APR 1400 that is the abbreviation of "Advanced Power Reactor with an electrical power output of 1400 MW". It is a pressurized water-cooled reactor developed in Korea. The main features of the APR 1400 are enhanced plant safety, economically favorable and convenient operation and maintenance. In terms of the electrical system of APR 1400, the electrical buses are separated into Class 1E A and Class 1E B. Class 1E is the systems that provides essential electric power to reactor shutdown, containment isolation, emergency core cooling, removal of residual heat, and preventing serious leakage of radioactive material to the environment. The list of Class 1E electrical loads is given in Table 2 [2]. 


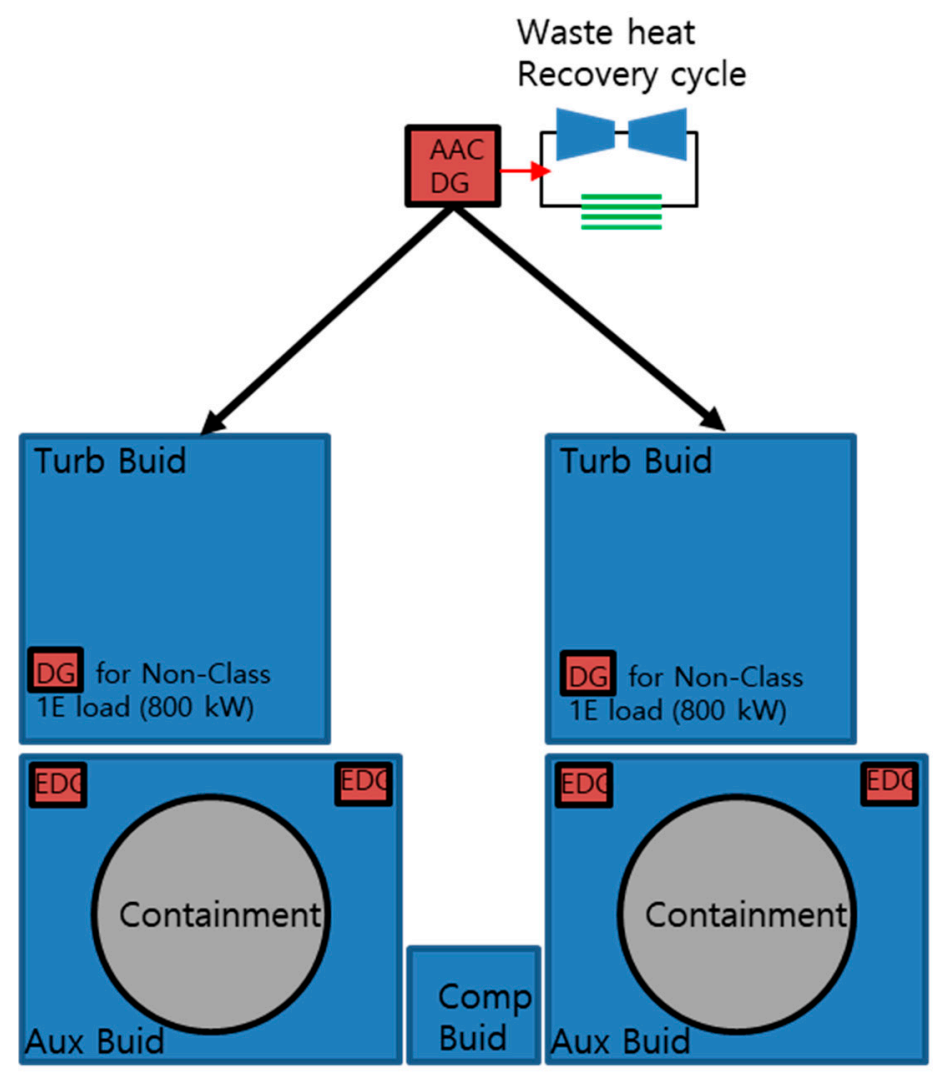

Figure 1. Schematic diagram of nuclear power plant and emergency power supply systems.

Table 2. Class 1E load and sequence at LOOP condition.

\begin{tabular}{ccc}
\hline Class 1E Components & Loading Sequence at LOOP & Power (kW) \\
\hline Load Sequence Group 2 & $0.0 \mathrm{~s}$ & $694.9 \times 2$ \\
Safety injection pump 1 & $5.0 \mathrm{~s}$ & 715 \\
Safety injection pump 3 & $10.0 \mathrm{~s}$ & 715 \\
Motor driven AFW pump & $15.0 \mathrm{~s}$ (if required) & 930.9 \\
Containment spray pump & $20.0 \mathrm{~s}$ & 738.1 \\
(That interlocks with shutdown cooling pump) & $25.0 \mathrm{~s}$ & 1225 \\
Component cooling water pump & $30.0 \mathrm{~s}$ & 636.8 \\
Essential service water pump & $35.0 \mathrm{~s}$ & 806.0 \\
Essential central chiller & $40.0 \mathrm{~s}$ & 304.9 \\
Essential ESW intake structure/ & & 7461.7 \\
CCW heat exchanger building chiller & & \\
Total Diesel Load on DBA/LOOP excluding & & \\
Manual Load & &
\end{tabular}

In case of failure of EDG, AAC DG supplies power to the Class 1E load instead of EDG.

For redundancy, independent EDGs supply power to each bus in LOOP and SBO accidents. Another $800 \mathrm{~kW}$ diesel generator in the turbine building is installed for supplying power to non-Class $1 \mathrm{E}$ as well if the EDG system becomes unavailable, AAC DG is electrically connected to operate safety systems instead of failed EDG. Table 3 contains the actual diesel generator specifications and vendors of APR 1400 which is constructed in Korea. In this study, AAC diesel generators of Shin Hanul is selected as the reference system. Figure 2 and Table 4 represent the schematic diagram and specification of diesel generator, respectively. 
Table 3. Status of EDG \& AAC DG of APR 1400 [3].

\begin{tabular}{ccccc}
\hline NPP site & Unit & No. of DG & Power (kW) & Vendor (Engine/Generator) \\
\hline \multirow{2}{*}{ Shin Kori } & EDG 3/4 & 4 & 8000 & Doosan-MDT: 16PC2.6B, Alstom \\
& AAC DG 3, 4 & 1 & 7200 & Doosan-MDT: 16PC2.6B, Alstom \\
\hline \multirow{2}{*}{ Shin Hanul } & EDG 1/2 & 4 & 7200 & Doosan-SEMT: 16PC2-5V400, Alstom \\
& AAC DG 1,2 & 1 & 7200 & Doosan-MDT: 18V32/40, Hyundai \\
\hline
\end{tabular}
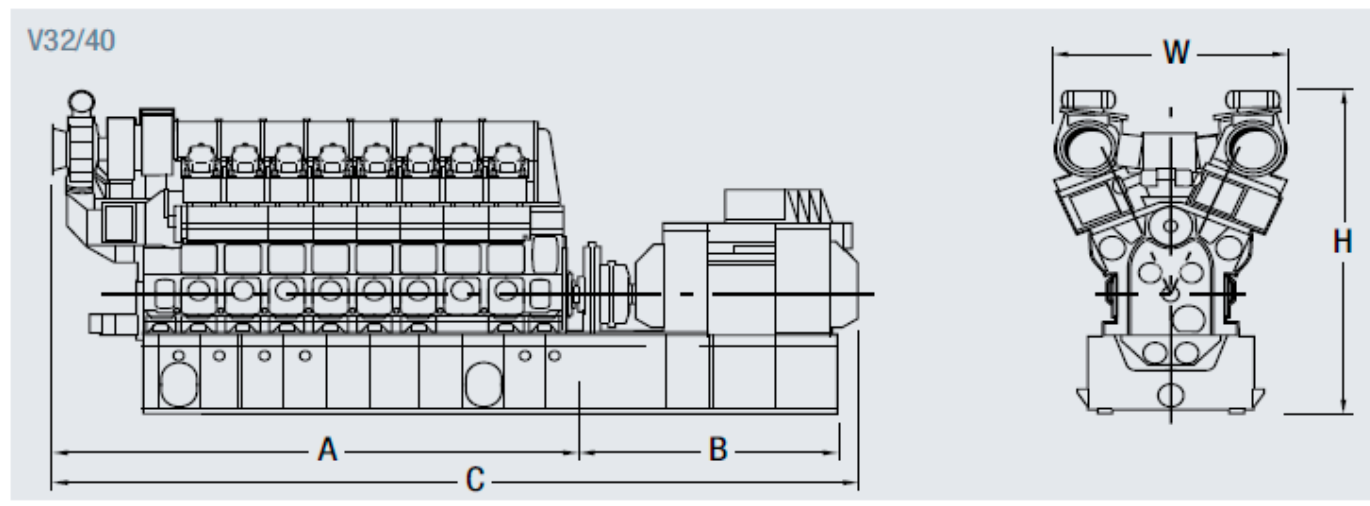

Figure 2. Schematic diagram of the Doosan-MDT: 18V32/40 for AAC diesel generator.

Table 4. Specifications of the Doosan-MDT: 18V32/40 for AAC diesel generator.

\begin{tabular}{cc}
\hline \multicolumn{2}{c}{ Specification } \\
\hline Engine & $18 \mathrm{~V} / 32 / 40$ \\
$\mathrm{~A}(\mathrm{~mm})$ & 8300 \\
$\mathrm{~B}(\mathrm{~mm})$ & 4450 \\
$\mathrm{C}(\mathrm{mm})$ & 12,750 \\
$\mathrm{H}(\mathrm{mm})$ & 5240 \\
$\mathrm{~W}(\mathrm{~mm})$ & 3500 \\
Weight (t) & 139 \\
\hline Exhaust gas data & \\
\hline Temperature at turbine outlet & $306^{\circ} \mathrm{C}$ \\
Mass flowrate & $15.1 \mathrm{~kg} / \mathrm{h}$ \\
Volume flowrate & $92,700 \mathrm{~m} 3 / \mathrm{h}$ \\
Pressure (abs.) & $1.03 \mathrm{bar}$ \\
Scavenged air data & $<0.03 \mathrm{bar}$ \\
\hline Permissible pressure drop after turbine & $25^{\circ} \mathrm{C}$ \\
\hline Temperature at the compressor inlet & $42^{\circ} \mathrm{C}$ \\
Temperature at the air cooler outlet & $14.7 \mathrm{~kg} / \mathrm{h}$ \\
Mass flowrate & $48,000 \mathrm{~m}{ }^{3} / \mathrm{h}$ \\
Volume flowrate & $3.2 \mathrm{bar}$ \\
Pressure (abs.)
\end{tabular}

From Table 4, it can be observed that the thermal potential of waste heat is quite high because a turbine outlet temperature is $306^{\circ} \mathrm{C}$, and the mass flowrate is $15.1 \mathrm{~kg} / \mathrm{h}$ which is equivalent to about 3 MWth heat so that it is quite valuable to use this high potential waste heat as an additional power for operating a safety system. For example, additional electric power from the waste heat recovery system can be used for extended operation of AAC DG while using the same amount of fuel or installing more safety components for improving redundancy or diversity to utilize additional power.

Consequently, the additional power from the AAC DG waste heat recovery system can be utilized in the nuclear safety system without revising the existing nuclear power plant's layout. In this paper, the supercritical carbon dioxide $\left(\mathrm{S}-\mathrm{CO}_{2}\right)$ bottoming cycles are studied in respect of best applicable 
options [4]. According to the review of the previous studies on the $\mathrm{S}-\mathrm{CO}_{2}$ cycles, it was verified that the $\mathrm{S}-\mathrm{CO}_{2}$ cycle has a strong potential to outperform the conventional steam cycle or organic Rankine cycle, particularly in waste heat recovery applications [5]. The major reasons are as follows: high efficiency at a moderate turbine inlet temperature $\left(450-750{ }^{\circ} \mathrm{C}\right)$ which significantly decreases maintenance and material problems, compact turbomachinery and heat exchangers which save the initial investment, and a simple layout which significantly reduces the overall footprint of the power plant [6]. The main feature of the $\mathrm{S}-\mathrm{CO}_{2}$ Brayton cycle is lower compression work than the other gas Brayton cycles because of S- $\mathrm{CO}_{2}$ fluid's its high density and low compressibility near the critical point. Therefore, this characteristic makes the $\mathrm{S}-\mathrm{CO}_{2}$ cycle having fewer material issues than water and consequently leads to a higher turbine inlet temperature [7]. Moreover, the cooling and chemistry control system of S- $\mathrm{CO}_{2}$ cycle are relatively simple than the steam Rankine cycle, the operation cost and the whole footprint of the power plant can be greatly decreased [8]. Because of these advantages, the $\mathrm{S}-\mathrm{CO}_{2}$ cycle is recently considered as the potential power cycle of conventional and renewable energy systems such as fossil fuel power plants, concentrated solar power systems, geothermal power plants, fuel cells, next generation nuclear power plants, and ship propulsion application.

In this paper, a comparison of six S-CO $\mathrm{CO}_{2}$ power cycle layouts recovering waste heat of s $7.2 \mathrm{MW}$ AAC DG is presented in order to evaluate which $\mathrm{S}-\mathrm{CO}_{2}$ cycle layout is the most qualified for a diesel engine application. Moreover, a sensitivity study of the cycles with design parameters was carried out, and thermodynamic performance results of the cycles were evaluated. After that, key components of the waste heat recovery system will be designed, and off-design analysis of the designed S- $\mathrm{CO}_{2}$ bottoming cycle will be presented.

\section{S- $\mathrm{CO}_{2}$ Bottoming Cycle Study for Diesel Generator}

\subsection{Cycle Layout and Analysis Method}

It is well known that the turbine inlet temperature and pressure ratio have great effect on the efficiency of gas Brayton cycle. However, overall cycle efficiency and a heat recovery factor should be carefully adopted for the application of waste heat recovery system because the factors are directly combined to the work recovered from the amount of transferred waste heat to the bottoming cycles.

Martelli et al. [9] noted that to obtain the net efficiency of the heat recovery cycle (calculated by dividing net produced work by the total heat recovered through ideally cooling flue gases to ambient temperature), the product of the cycle efficiency (net produced work divided by recovered heat) and the heat recovery factor (recovered heat divieded by ideally recoverable heat) should be calculated. Hence, when optimizing heat recovery cycles, instead of maximizing the cycle efficiency, maximizing the product of cycle efficiency and heat recovery factor becomes more valid.

According to Heo et al. [10], the performance indicator of bottoming cycles can be simply expressed by adopting the waste heat recovery index (WHRI):

$$
\begin{aligned}
& \mathrm{WHRI}=\chi \cdot \eta_{\text {cycle }} \\
& \chi=\frac{\text { thermal power absorbed by the bottoming cycle }}{\text { total net thermal power recoverable dueto thermal power }} \\
& =\frac{\dot{\mathrm{m}}_{\text {exhaust }}\left(\mathrm{h}\left(\mathrm{T}_{\text {exhaust,in }}, \mathrm{P}_{\text {exhaust,in }}\right)-\mathrm{h}\left(\mathrm{T}_{\text {exhaust,out }}, \mathrm{P}_{\text {exhaust,out }}\right)\right)}{\dot{\mathrm{m}}_{\text {exhaust }}\left(\mathrm{h}\left(\mathrm{T}_{\text {exhaust,max }}, \mathrm{P}_{\text {exhaust,max }}\right)-\mathrm{h}\left(\mathrm{T}_{\text {ambient }}, \mathrm{P}_{\text {ambient }}\right)\right)} \\
& \eta_{\text {cycle }}=\frac{\text { net work generated by the bottoming cycle }}{\text { thermal power absorbed by the bottoming cycle }} \\
& =\frac{\mathrm{W}_{\text {turbine }}-\mathrm{W}_{\text {compressor }}}{\dot{\mathrm{m}}_{\text {exhaust }}\left(\mathrm{h}\left(\mathrm{T}_{\text {exhaust, }, \text { }}, \mathrm{P}_{\text {exhaust,in }}\right)-\mathrm{h}\left(\mathrm{T}_{\text {exhaust,out }}, \mathrm{P}_{\text {exhaust,out }}\right)\right)} \\
& \therefore \text { WHRI }=\frac{\text { net work generated by the bottoming cycle }}{\text { total net thermal power recoverable due to thermal power }} \\
& =\frac{\mathrm{W}_{\text {turbine }}-\mathrm{W}_{\text {compressor }}}{\mathrm{m}_{\text {exhaust }}\left(\mathrm{h}\left(\mathrm{T}_{\text {exhaust,max }}, \mathrm{P}_{\text {exhaust,max }}\right)-\mathrm{h}\left(\mathrm{T}_{\text {ambient }}, \mathrm{P}_{\text {ambient }}\right)\right)}
\end{aligned}
$$

where $h(T, P)$ denotes the calculated enthalpy values from the given temperature and pressure values. 
By utilizing this performance index, various bottoming cycle designs can be assessed with a more applicable framework especially for the waste heat recovery systems' performance. This indicator matches to the concept of cycle net efficiency, except that it evaluates the performance replacing the cycle heat input with maximum obtainable heat from the heat source for the bottoming cycle.

The WHRI values for various $\mathrm{S}-\mathrm{CO}_{2}$ cycle layouts are obtained. Parametric sensitivity of the design variables such as turbine outlet pressure (or pressure ratio), $\mathrm{CO}_{2}$ mass flow rate, first compressor outlet pressure, and flow splits, with respect to cycle performance, is summarized. Furthermore, the cycle minimum pressure is placed as a major design parameter to be optimized.

An in-house code is used for the cycle optimization. The code is developed by the research team at KAIST, and it is named as KAIST-Closed Cycle Design (KAIST-CCD) code [11-13]. The code is based on MATLAB. Enthalpy and fluid properties for calculation in the code are referred from the NIST reference fluid thermodynamic and transport properties database (REFPROP) [14]. Figures 3 and 4 show the algorithm of the code structure and the partial heating cycle layout. This layout is chosen to illustrate the process of the cycle analysis. Firstly, the recuperator cold side inlet flow condition (point 5) and the heater 2 hot side inlet flow condition (point 10) are assumed. Through the component models (compressor, turbine, recuperator, heater, cooler, and mixing tee), the component inlet and outlet conditions are calculated. Then, the heat input from exhaust gas with exhaust inlet and outlet conditions is calculated. If the cycle calculation error remains above $10^{-5}$, the assumed values are updated to the newly calculated conditions, and the cycle calculation is repeated. If the error is less than $10^{-5}$, the code calculation terminates and prints output results. The partial heating cycle and other layouts are evaluated by the KAIST-CCD code through a similar algorithm.

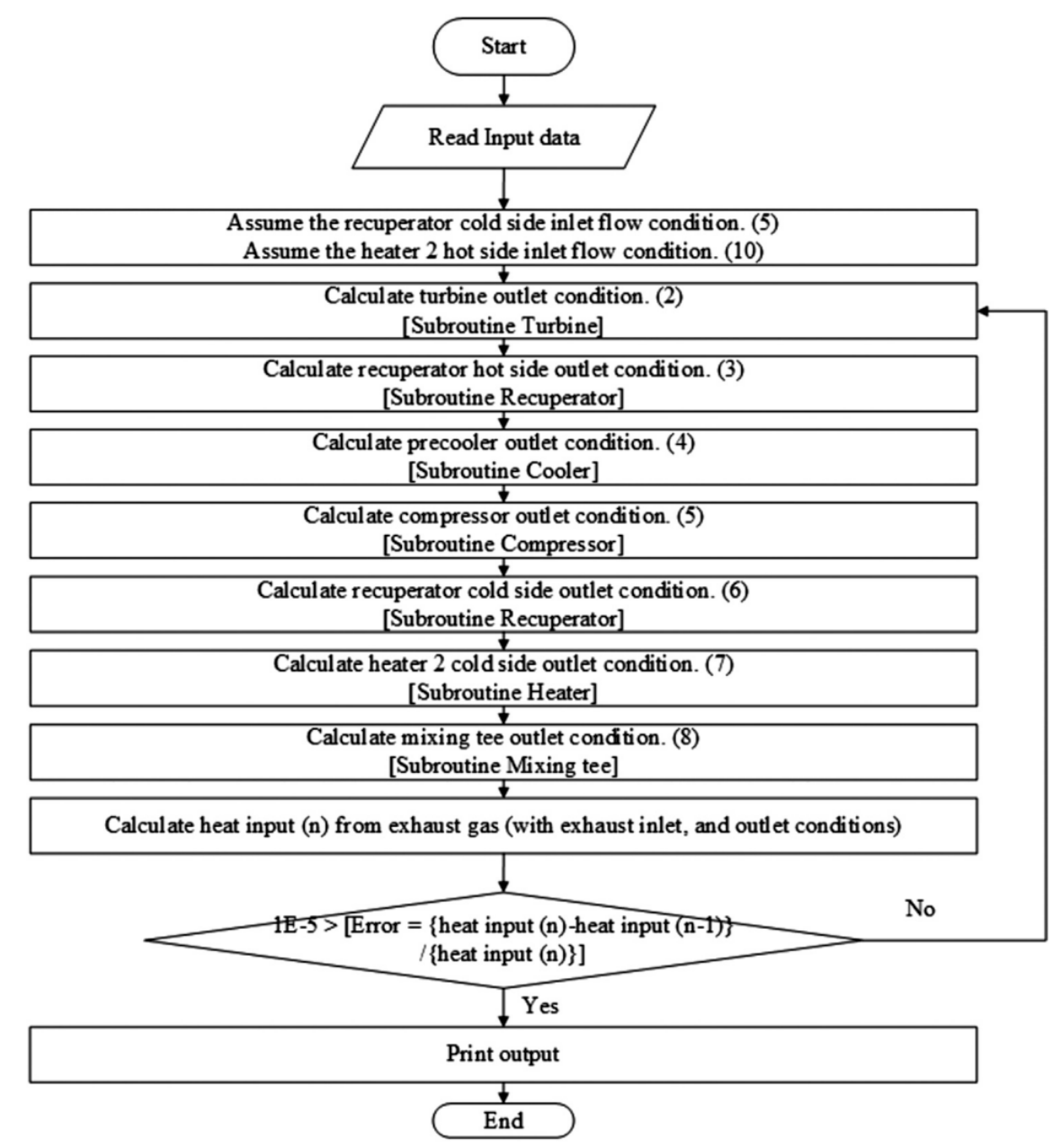

Figure 3. The cycle design code algorithm for the partial heating cycle. 


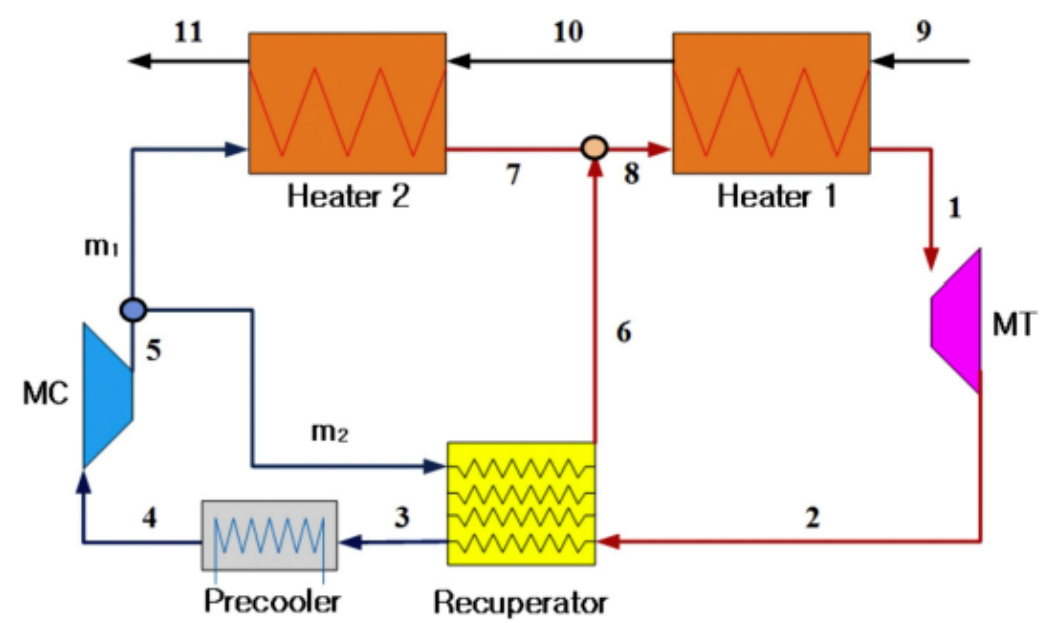

Figure 4. Layout of partial heating cycle for the algorithm illustration purpose.

The full power of the reference four strokes diesel engine is $9 \mathrm{MW}$ with 720 or $750 \mathrm{rpm}$, but around $80 \%$ of full power is used for the emergency electrical load due to safety margin. Table 5 shows the main specification of the AAC DG which influences the design of the $\mathrm{S}-\mathrm{CO}_{2}$ bottoming cycle. Table 6 displays the values of exhaust gas source, properties, and mole fraction of each species [15]. The modeling of each $\mathrm{S}-\mathrm{CO}_{2}$ cycle adopts the exhaust gas properties of the topping cycle to evaluate the power output of the $\mathrm{S}-\mathrm{CO}_{2}$ cycle.

Table 5. Specifications of AAC DG.

\begin{tabular}{cc}
\hline \multicolumn{2}{c}{ Exhaust Gas } \\
\hline Power capacity & $7.2 \mathrm{MWe}(80 \%$ load $)$ \\
Exhaust temperature at turbine outlet & $306^{\circ} \mathrm{C}$ \\
Pressure (abs.) & $1.03 \mathrm{bar}$ \\
Mass flow rate & $15.1 \mathrm{~kg} / \mathrm{s}$ \\
\hline \multicolumn{2}{c}{ Scavenge Air } \\
\hline Air temperature at compressor inlet & $25{ }^{\circ} \mathrm{C}$ \\
Air temperature at compressor outlet & $42{ }^{\circ} \mathrm{C}$ \\
Pressure (abs.) & $3.2 \mathrm{bar}$ \\
Mass flow rate & $14.7 \mathrm{~kg} / \mathrm{s}$ \\
\hline
\end{tabular}

Table 6. Exhaust gas properties, source, and mole fraction of each species.

\begin{tabular}{cccc}
\hline & Species & Mole Fraction & Source \\
\hline \multirow{4}{*}{ Major species } & Nitrogen $\left(\mathrm{N}_{2}\right)$ & 0.78 & Inlet air \\
& Oxygen $\left(\mathrm{O}_{2}\right)$ & 0.13 & Inlet air \\
& Carbon dioxide $\left(\mathrm{CO}_{2}\right)$ & 0.06 & Oxidation of fuel carbon \\
& Water vapor $\left(\mathrm{H}_{2} \mathrm{O}\right)$ & 0.03 & Oxidation of fuel hydrogen \\
\hline
\end{tabular}

\subsection{Assumptions and Constraints}

To observe the performance of various cycle layouts under the same exhaust gas condition, several constraints are assumed. Here, the maximum operating pressure is limited to $22.0 \mathrm{MPa}$. This value corresponds to the maximum pressure of the existing ultra-supercritical steam Rankine cycle which already operates under significantly high pressure, and its maximum temperature also surpasses $600{ }^{\circ} \mathrm{C}$ [16]. The maximum operating pressure is limited to $22.0 \mathrm{MPa}$ to avoid high capital costs for the piping systems and to generate a realistic $\mathrm{S}-\mathrm{CO}_{2}$ power cycle model. The maximum temperature (turbine inlet temperature) falls below the exhaust temperature of the topping cycle. Finally, the minimum cycle temperature (compressor inlet temperature) is restricted to $25.0^{\circ} \mathrm{C}$ so that 
the heat sink temperature does not fall too far from the general room temperature while the cycle fluid remains in the supercritical state [17].

The cycle variables are summarized in Table 7 , including the cycle minimum pressure, pressure drop of the heat exchangers, turbomachinery efficiency and heat exchanger effectiveness. Particularly, turbomachinery efficiency and heat exchanger effectiveness were based on the reference in order to conduct sensitivity analyses of cycles. The previous research results have shown that the cost of heat exchanger sharply increases when the heat exchanger effectiveness value is above 0.95 [18]. The pressure drop values in $\mathrm{CO}_{2}$ side of all heat exchangers were assumed to be $0.5 \%$ of the system pressure.

Table 7. Cycle variables of $\mathrm{S}-\mathrm{CO}_{2}$ bottoming cycles.

\begin{tabular}{|c|c|c|c|}
\hline \multicolumn{2}{|c|}{ Content } & Unit & Value \\
\hline \multicolumn{2}{|c|}{ Heat source } & - & $\begin{array}{c}\text { Exhaust gas only or exhaust } \\
\text { gas \& scavenge air }\end{array}$ \\
\hline \multicolumn{2}{|c|}{ Cycle minimum pressure } & \multirow{2}{*}{$\mathrm{MPa}$} & 22.0 \\
\hline Pressure drop & $\begin{array}{c}\text { Exhaust gas/Scavenge air } \\
\text { Others }\end{array}$ & & $\begin{array}{l}0.202 \text { (=2bar) } \\
0.101 \text { (=1bar) }\end{array}$ \\
\hline $\begin{array}{l}\text { Temperature } \\
\text { conditions }\end{array}$ & $\begin{array}{c}\text { Air } \\
\text { Cooling water } \\
\text { Min. temp. difference } \\
\text { Compressor inlet }\end{array}$ & ${ }^{\circ} \mathrm{C}$ & $\begin{array}{l}25 \\
25 \\
10 \\
35\end{array}$ \\
\hline $\begin{array}{l}\text { Turbomachinery } \\
\text { efficiency }\end{array}$ & $\begin{array}{l}\text { Turbine } \\
\text { Compressor }\end{array}$ & $\%$ & $\begin{array}{l}88 \\
75\end{array}$ \\
\hline $\begin{array}{l}\text { Heat exchanger } \\
\text { effectiveness }\end{array}$ & $\begin{array}{l}\text { Exhaust gas } \\
\text { Scavenge air } \\
\text { Precooler } \\
\text { Recuperator }\end{array}$ & $\%$ & $\begin{array}{l}90 \\
90 \\
90 \\
95\end{array}$ \\
\hline
\end{tabular}

When designing heat exchangers, in particular when calculating the heat transfer, it is known that the specific heat capacity property of the working fluid is very important because the specific heat capacity has a great influence on the heat exchanger effectiveness as well as cycle efficiency. Generally, the specific heat capacity is considered as a constant value due to a little change with pressure and temperature. However, this assumption is inappropriate for the supercritical fluid since the property of the specific heat capacity changes substantially near the critical point. In this study, all properties as well as the specific heat capacity were directly called from the REFPROP.

\subsection{Sensitivity Analysis of $\mathrm{S}-\mathrm{CO}_{2}$ Cycles}

In the $\mathrm{S}-\mathrm{CO}_{2}$ cycle research community, a study for the $\mathrm{S}-\mathrm{CO}_{2}$ bottoming cycle is mostly performed for the patent application; therefore, the patented cycle's optimization results are proprietary information which is not openly accessible to the researchers in this field. Thus, in this paper, the academic contributions are presenting the analysis results of various $\mathrm{S}-\mathrm{CO}_{2}$ cycle layouts for bottoming cycle application to generate database for the future study. For the waste heat recovery process, all the selected cycle layouts are free from patent and searched from open literatures as well as a newly suggested cycle by the authors. For this purpose, cycle layouts suggested by various $\mathrm{S}-\mathrm{CO}_{2}$ power system companies are excluded.

\subsubsection{Simple Recuperation Cycle}

Firstly, a simple recuperated cycle [19] is analyzed as a basic cycle to compare the cycle performance of other $\mathrm{S}-\mathrm{CO}_{2}$ cycles. Five different cycles were selected as candidates and number of components and design variables are summarized in Table 8. The simple recuperated cycle has $515 \mathrm{kWe}$ net produced work (see Figure 5) which is the lowest among six cycles considered in this paper because EG heat 
exchanger only absorbs 2.55 MWth of waste heat due to the low temperature difference between hot side and cold side of EG heat exchanger. Although the simple recuperated cycle produces the lowest net work, its footprint is relatively small because of the lowest total exchanged heat in heat exchangers and the fewest number of components.

Table 8. The design variables and the number of components of $\mathrm{S}-\mathrm{CO}_{2}$ cycles.

\begin{tabular}{|c|c|c|}
\hline Cycle Layout & $\begin{array}{l}\text { The Number of } \\
\text { HX/TB/CP }\end{array}$ & Design Variables \\
\hline (1-1) Simple recuperation & $3 / 1 / 1$ & $\mathrm{CO}_{2}$ Mass flow rate, turbine outlet pressure \\
\hline (1-2) Simple recuperation with SA heat & $4 / 1 / 1$ & $\mathrm{CO}_{2}$ Mass flow rate, turbine outlet pressure \\
\hline (2-1) Recompression cycle with SA heat & $5 / 1 / 2$ & $\begin{array}{l}\mathrm{CO}_{2} \text { Mass flow rate, turbine outlet pressure, } \\
\text { split ratio } 1 \text {, split ratio } 2\end{array}$ \\
\hline (3-1) Partial heating cycle & $4 / 1 / 1$ & $\begin{array}{c}\mathrm{CO}_{2} \text { Mass flow rate, turbine outlet pressure, } \\
\text { split ratio }\end{array}$ \\
\hline (3-2) Partial heating cycle with SA heat & $4 / 1 / 1$ & $\begin{array}{c}\mathrm{CO}_{2} \text { Mass flow rate, turbine outlet pressure, } \\
\text { split ratio }\end{array}$ \\
\hline $\begin{array}{l}\text { (3-3) Modified partial heating cycle with } \\
\text { SA heat }\end{array}$ & $4 / 1 / 1$ & $\begin{array}{c}\mathrm{CO}_{2} \text { Mass flow rate, turbine outlet pressure, } \\
\text { split ratio }\end{array}$ \\
\hline
\end{tabular}

WHRI $=11.6 \%$

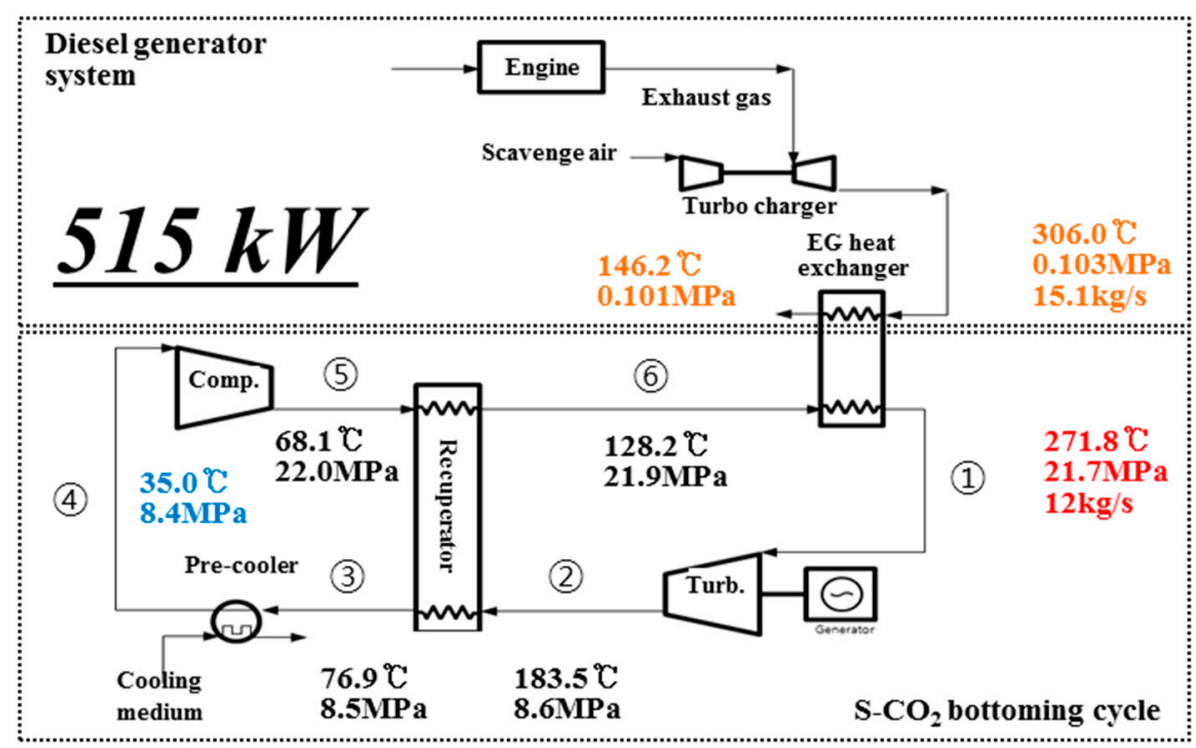

Figure 5. Configuration of simple recuperation cycle.

\subsubsection{Simple Recuperation Cycle with SA Heat}

The S- $\mathrm{CO}_{2}$ power conversion system has considered the only single waste heat source from various power plants. However, diesel engine application has dual heat source from exhaust gas and scavenge air as shown in Figure 6. To additionally use the SA heat from AAC DG turbocharger, simple recuperation cycle was modified. It has one more waste heat exchanger than the simple recuperation cycle for SA heat absorption.

The T-s diagram of the simple recuperation cycle with SA heat is shown in Figure 7. Figure 8 shows the variation of net produced work with respect to the selected design variables. The simple recuperated cycle with SA heat has $12.8 \%$ WHRI and $568 \mathrm{kWe}$ net produced work which is $1.2 \%$ and $53 \mathrm{kWe}(+10.3 \%)$ higher than the simple recuperated cycle. By applying dual heat sources from exhaust gas and scavenge air, waste heat recovery is sharply increased from 2.55 MWth to 3.21 MWth $(+25.9 \%)$ with one more heat exchanger. 
$W H R I=12.8 \%$

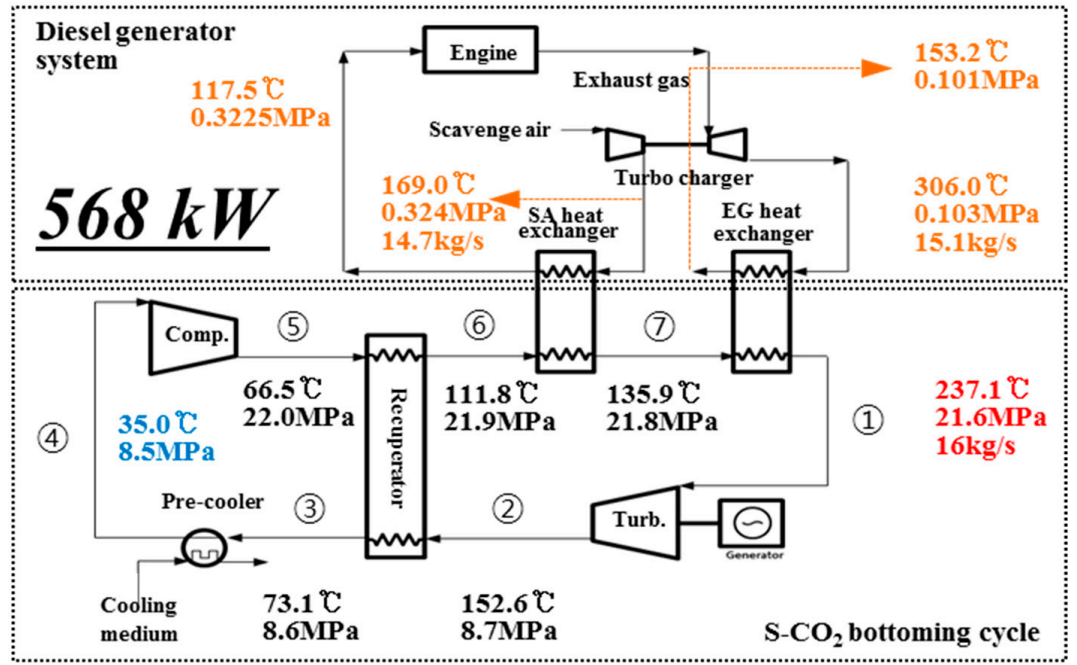

Figure 6. Configuration of simple recuperation cycle with SA heat.

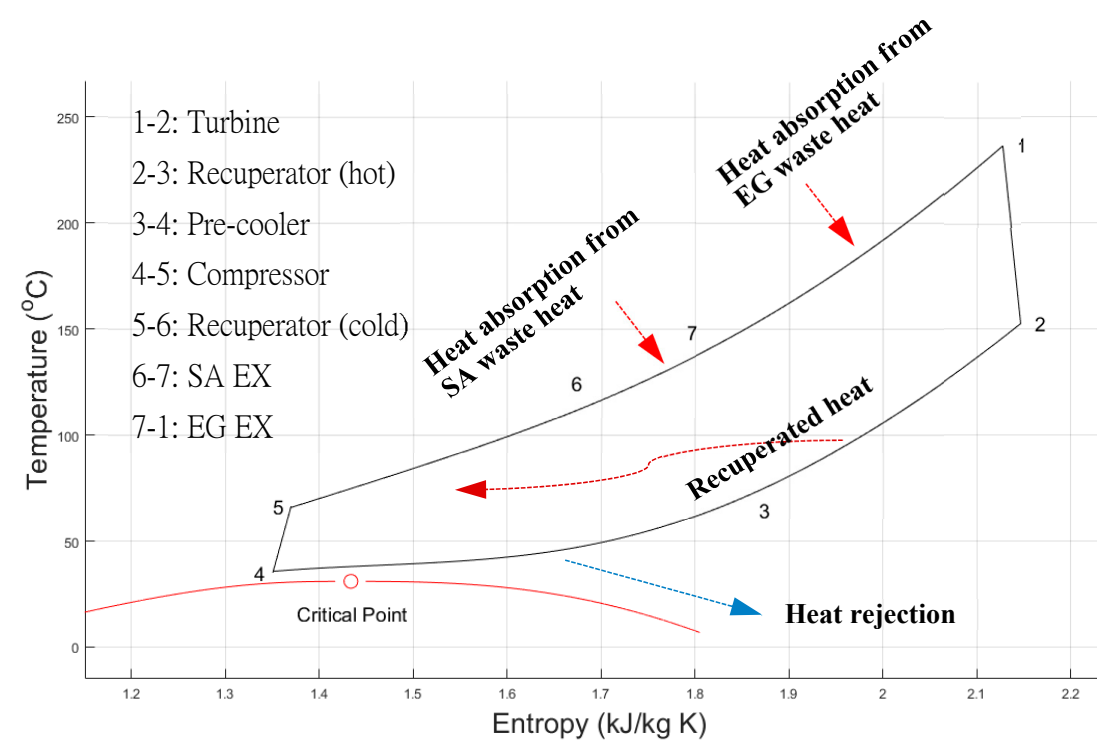

Figure 7. T-s diagram of simple recuperation cycle with SA heat.

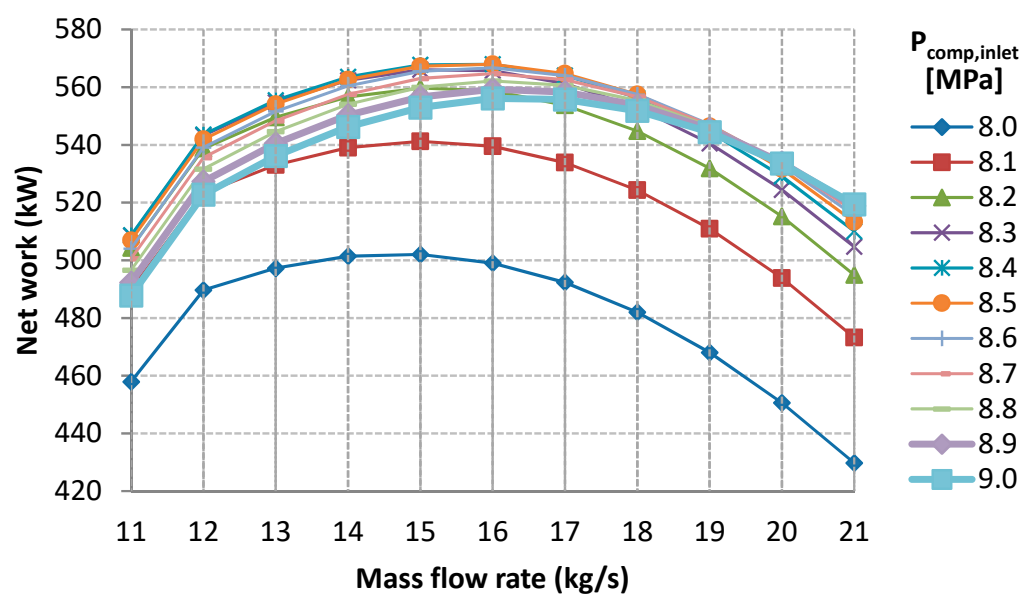

Figure 8. Net work dependence with $\mathrm{CO}_{2}$ mass flow rate, and turbine outlet pressure. 


\subsubsection{Modified Recompression Cycle with SA Heat}

According to the previous works [20,21], recompression cycle which has split flow and two different compressors is one of the representative layout of $\mathrm{S}-\mathrm{CO}_{2}$ cycle since it provides the highest efficiency. The split flow can minimize waste of available heat (see Figure 9) and it enhances overall cycle efficiency. However, verification for the suitability of a recompression cycle as a bottoming cycle is needed since the net produced work is a more important factor than the thermal efficiency in the design of bottoming cycle.

The T-s diagram of recompression cycle with SA heat is shown in Figure 10. The modified recompression cycle with SA heat has one more heat exchanger and one more compressor than the simple recuperation with SA heat. The net produced work variation with respect to the selected design variables is shown in the Figure 11. In this paper, flow split is expressed as $m_{1} /\left(m_{1}+m_{2}\right)$. As shown in Figure 11, the thermal efficiency is reduced but the heat input has the reverse trend as flow split decreases. In other words, higher net produced work is expected as flow split is closer to zero since the increase of heat input is greater than the decrease of thermal efficiency. If the flow split is equal to zero, this cycle is similar to a partial heating cycle with SA heat; therefore, the recompression cycle is not suitable for the bottoming cycle application.

$W H R I=13.8 \%$

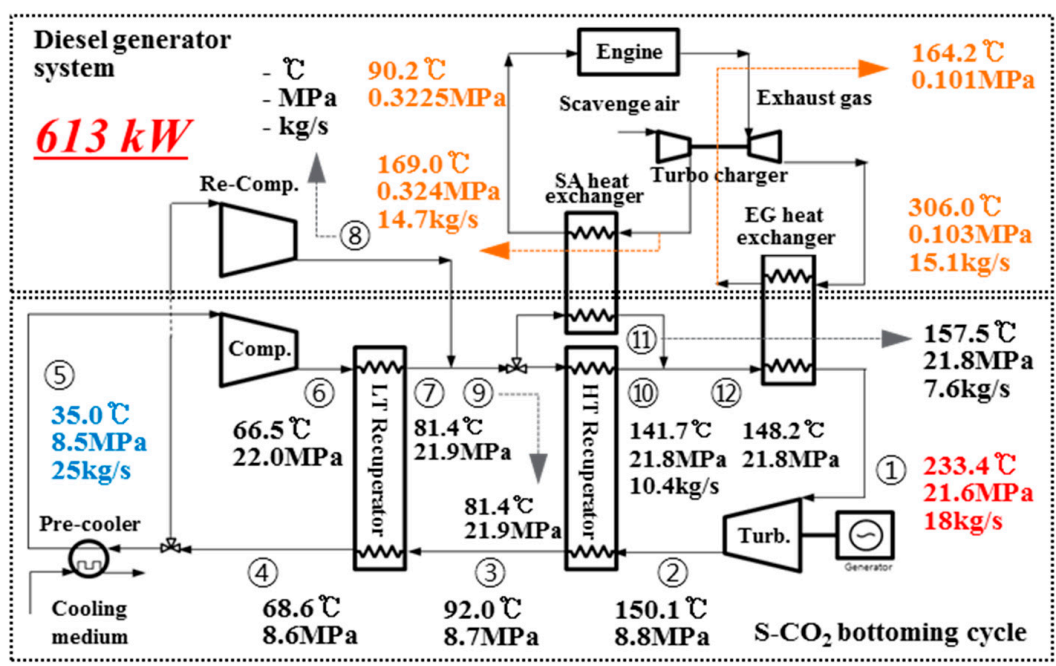

Figure 9. Configuration of recompression cycle with SA heat.

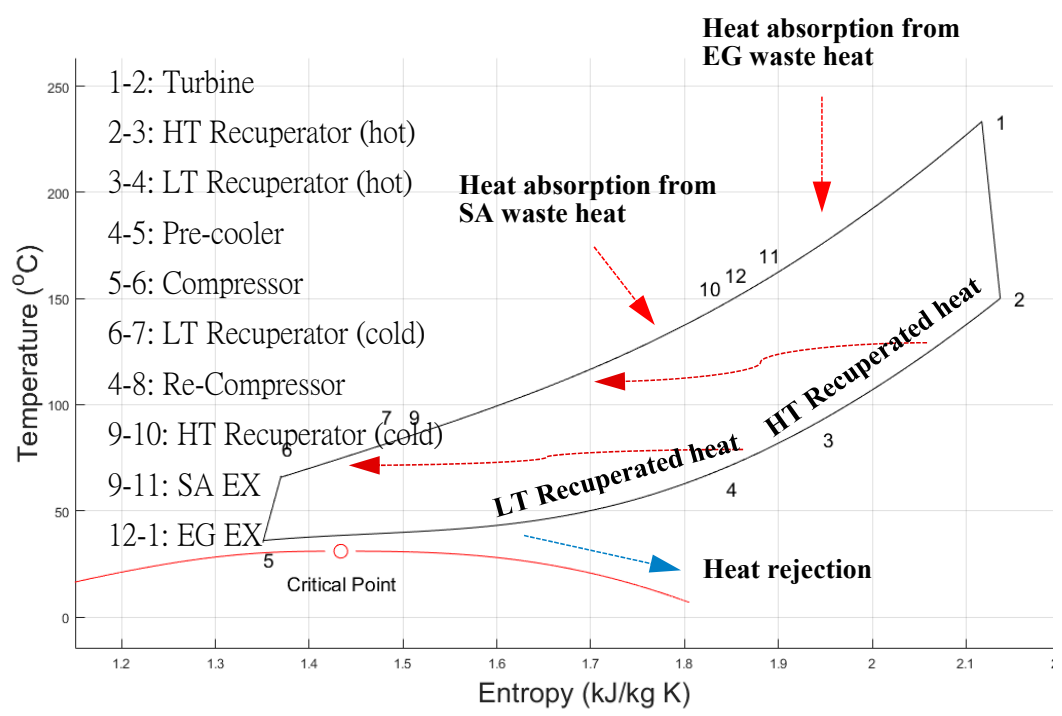

Figure 10. T-s diagram of recompression cycle with SA heat. 

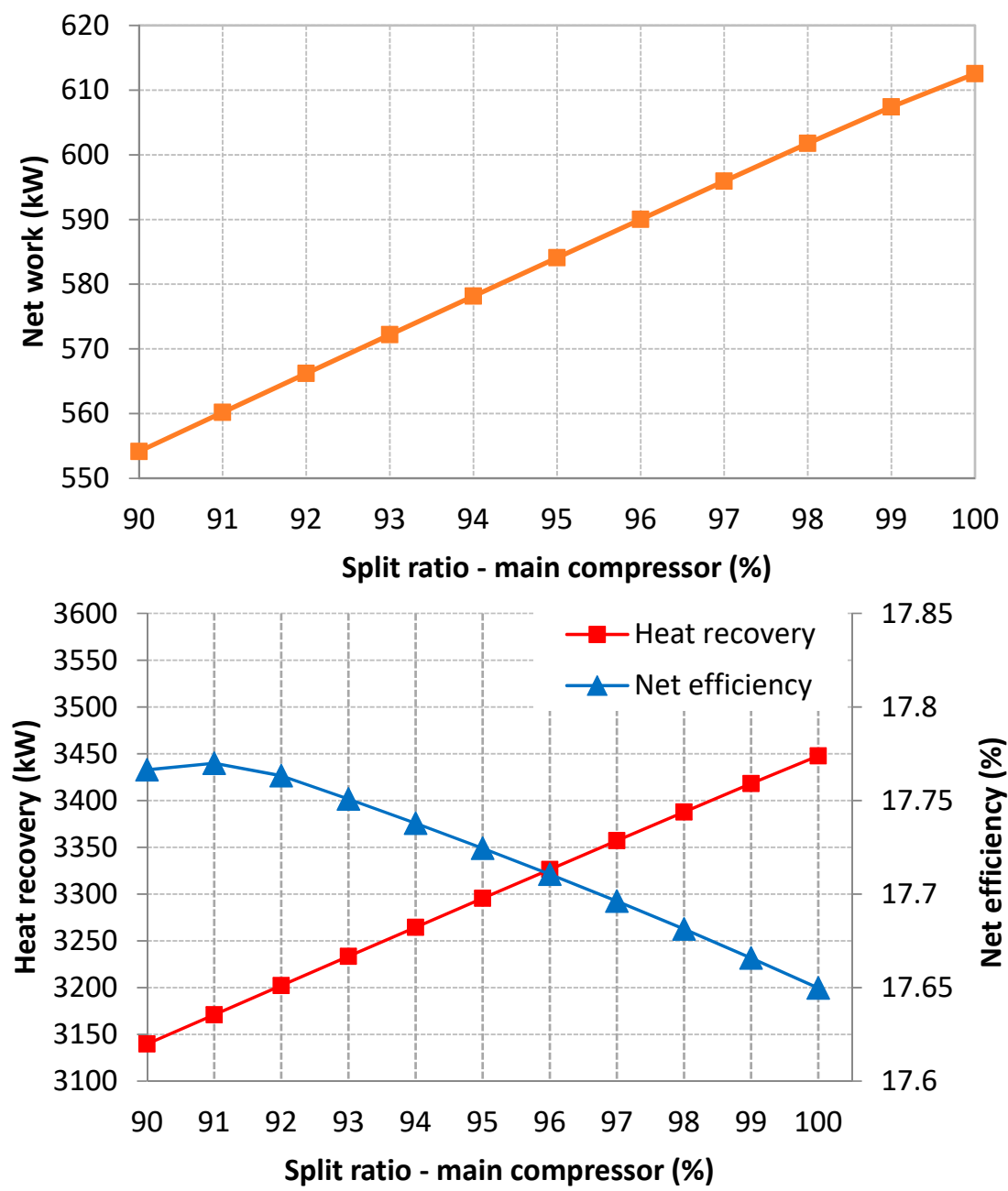

Figure 11. Net produced work dependency on flow split (upper), heat recovery and net efficiency dependency on flow split (bottom).

\subsubsection{Partial Heating Cycle}

The partial heating cycle [22] which has the same number of heat exchangers with the simple recuperation with SA heat is analyzed. Since it has a different design variable and flow split ratio from the simple recuperation with SA heat, the effect of flow split ratio has to be investigated again (see Figure 12). Figure 13 shows the T-s diagram of the partial heating cycle for the $\mathrm{S}-\mathrm{CO}_{2}$ bottoming cycle. The net produced work variation with respect to the selected design variables is shown in Figure 14.

Unlike the simple recuperation with SA heat, this cycle achieves quite high $607 \mathrm{kWe}$ net produced work for its small number of components (only four heat exchangers). From the sensitivity analysis, the net produced work is maximized, and the optimal absorbed heat from the exhaust and recuperated heat is found by controlling the flow fraction to the recuperator and the second heater. As shown in Figure 12, a final exhaust gas temperature is $77.4^{\circ} \mathrm{C}$ which is relatively lower temperature, and this makes higher absorbed heat from the exhaust gas of a diesel engine. The partial heating cycle is expected to show the best performance among the selected cycle layouts, because the partial heating cycle has a relatively large recuperated heat with a simple layout and a small number of components. 
$W H R I=13.7 \%$

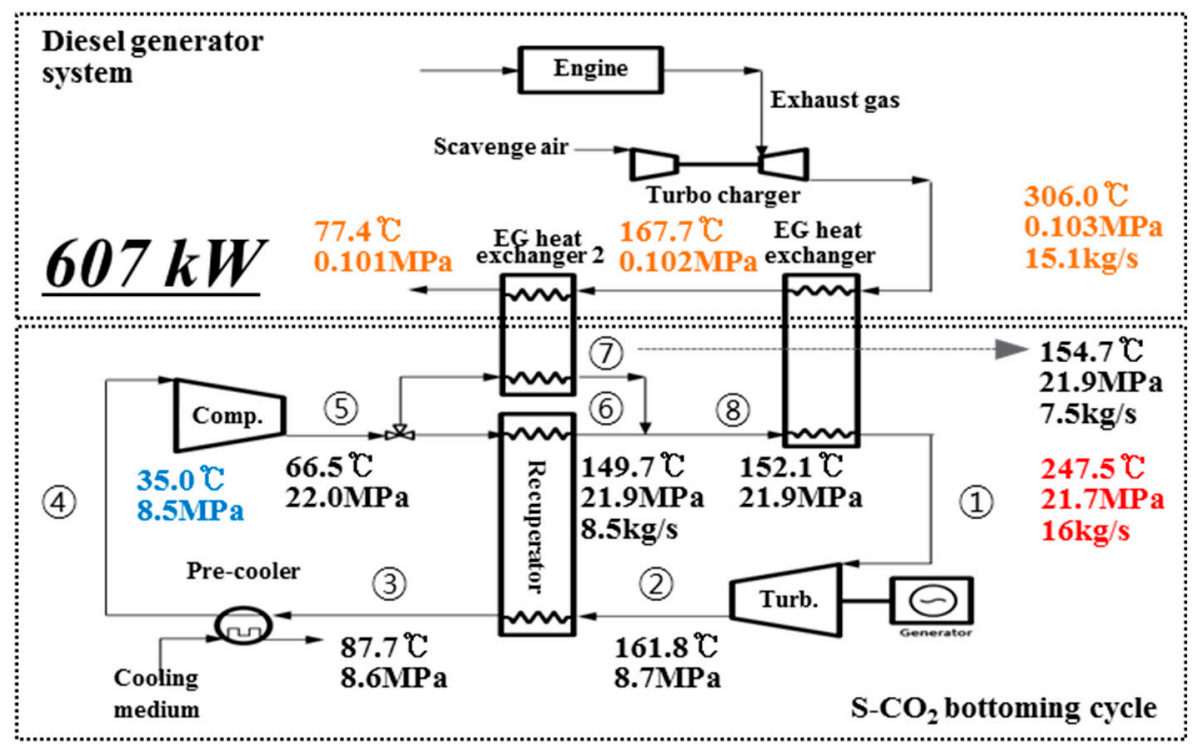

Figure 12. Configuration of partial heating cycle.

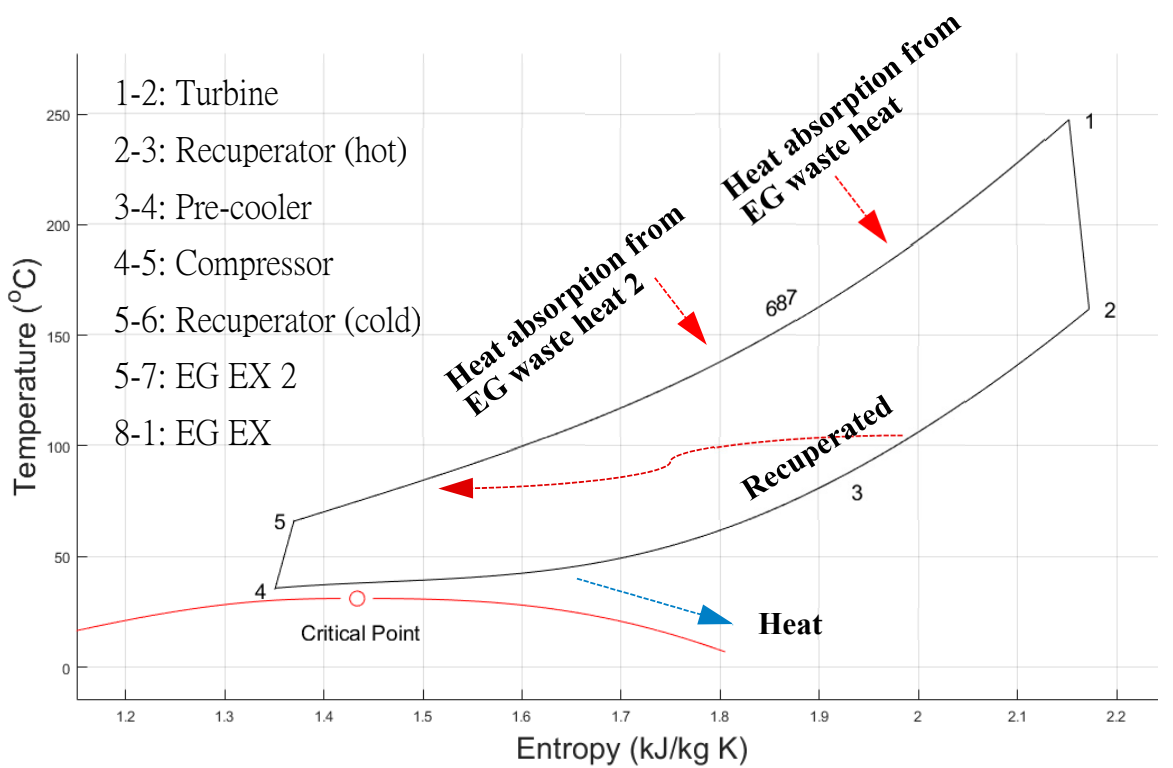

Figure 13. T-s diagram of the partial heating cycle.

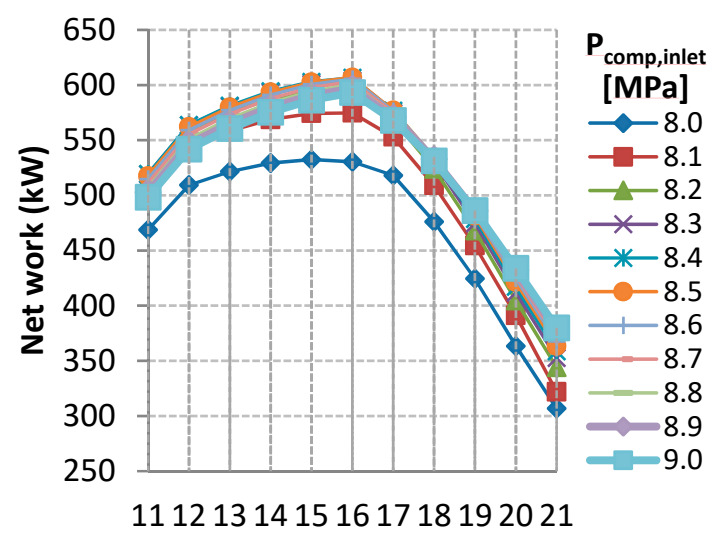

Mass flow rate $(\mathrm{kg} / \mathrm{s})$

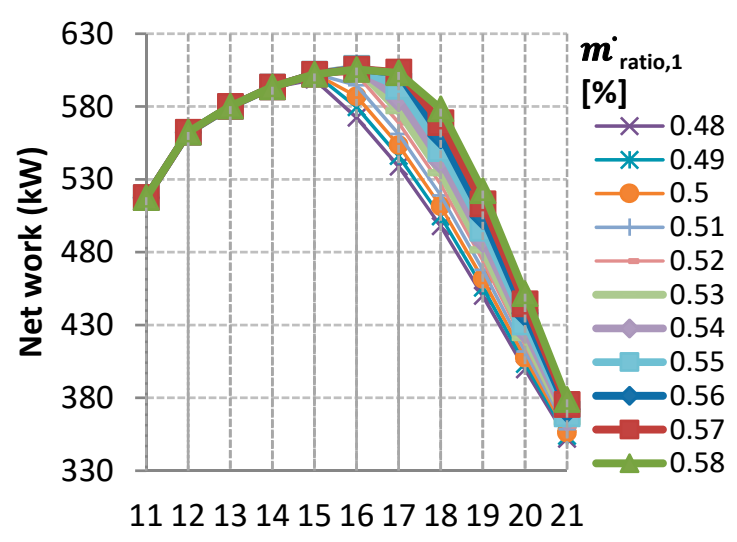

Mass flow rate $(\mathrm{kg} / \mathrm{s})$

Figure 14. Net work dependence with mass flow rate, flow split, and turbine outlet pressure. 


\subsubsection{Partial Heating Cycle with SA Heat}

The partial heating cycle with SA heat modified from partial heating cycle is analyzed to use the SA heat from the AAC DG turbocharger (see Figure 15) additionally. It has the same number of heat exchangers and turbomachinery with the partial heating cycle, but EG heat exchanger 2 was changed to SA heat exchanger for absorption of SA heat.

\section{WHRI $=13.9 \%$}

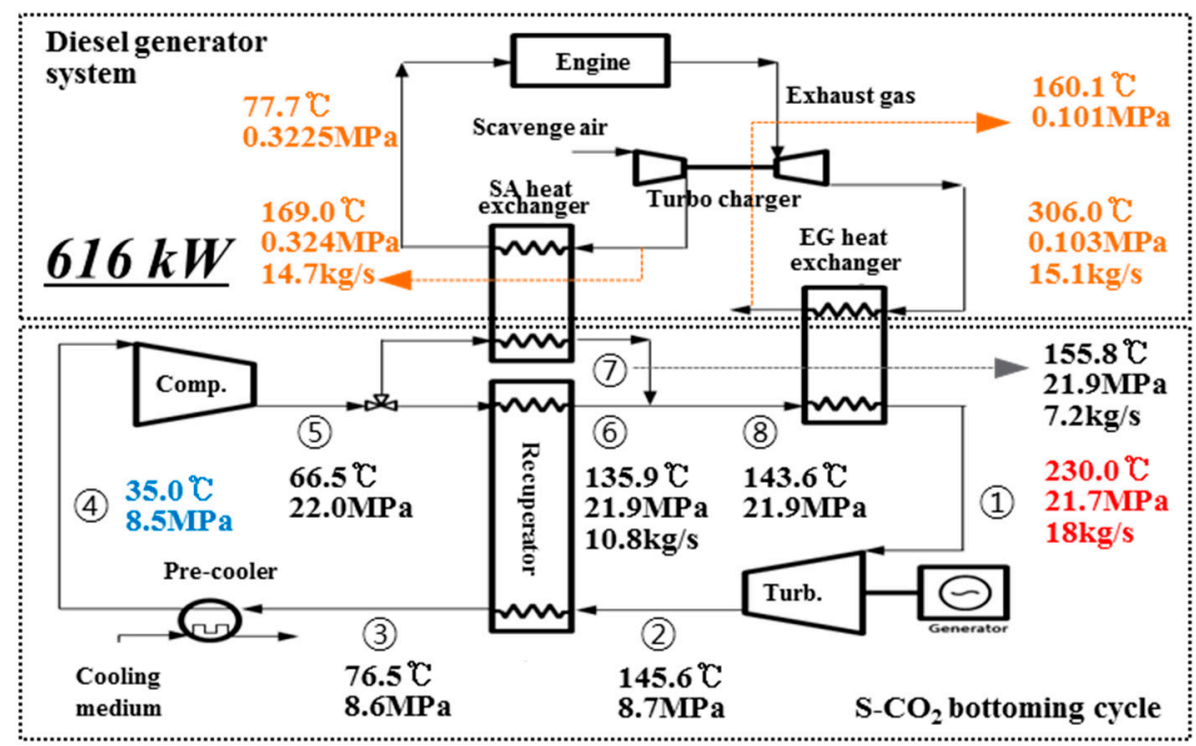

Figure 15. Configuration of partial heating cycle with SA heat.

The T-s diagram of the partial heating cycle with SA heat is shown in Figure 16. Figure 17 shows the net produced work variation with respect to the design variables. The partial heating cycle with SA heat has $13.9 \%$ WHRI and $616 \mathrm{kWe}$ net produced work which is the $0.2 \%$ and $9 \mathrm{kWe}(+1.5 \%)$ higher than the partial heating cycle. Unlike the simple recuperation cycle with SA heat, waste heat recovery is increased slightly from 3.63 MWth to 3.70 MWth $(+1.9 \%)$ since the outlet temperature of EG heat exchanger is similar to the outlet temperature of scavenge air.

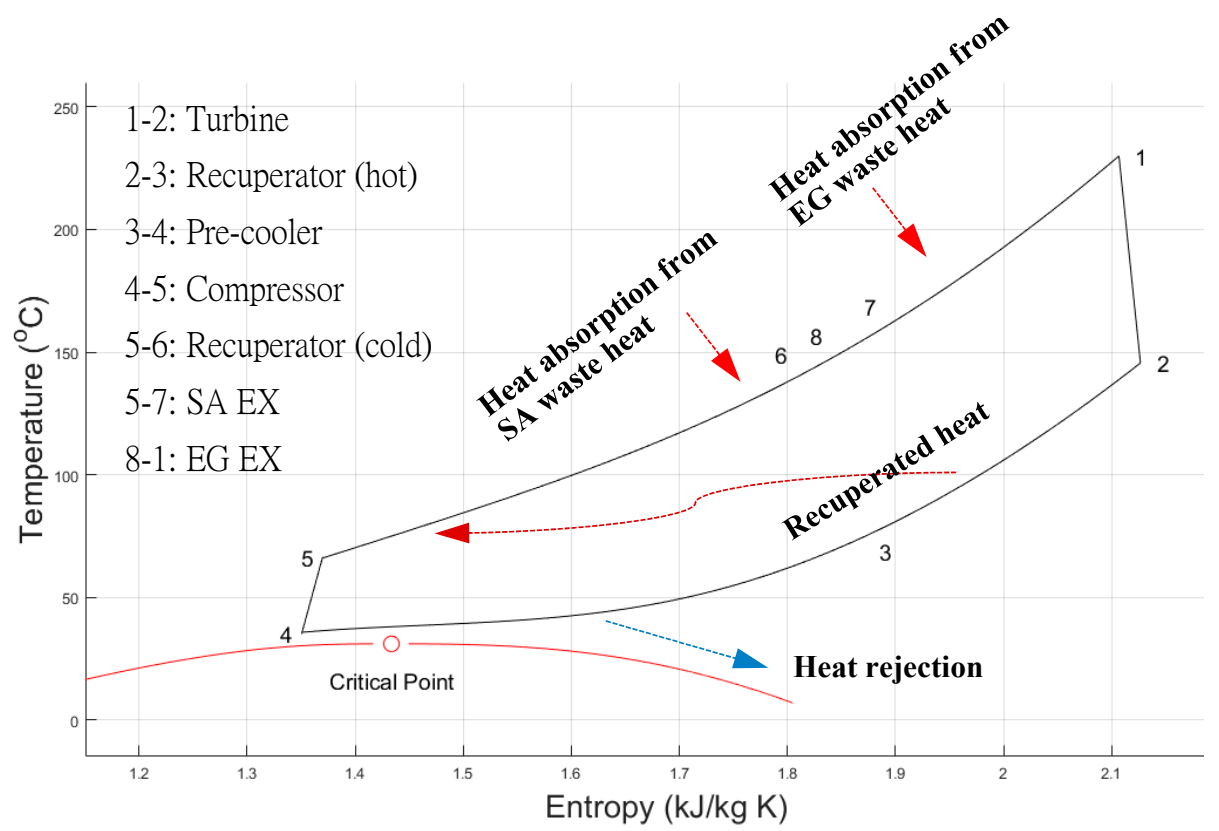

Figure 16. T-s diagram of the partial heating cycle with SA heat. 

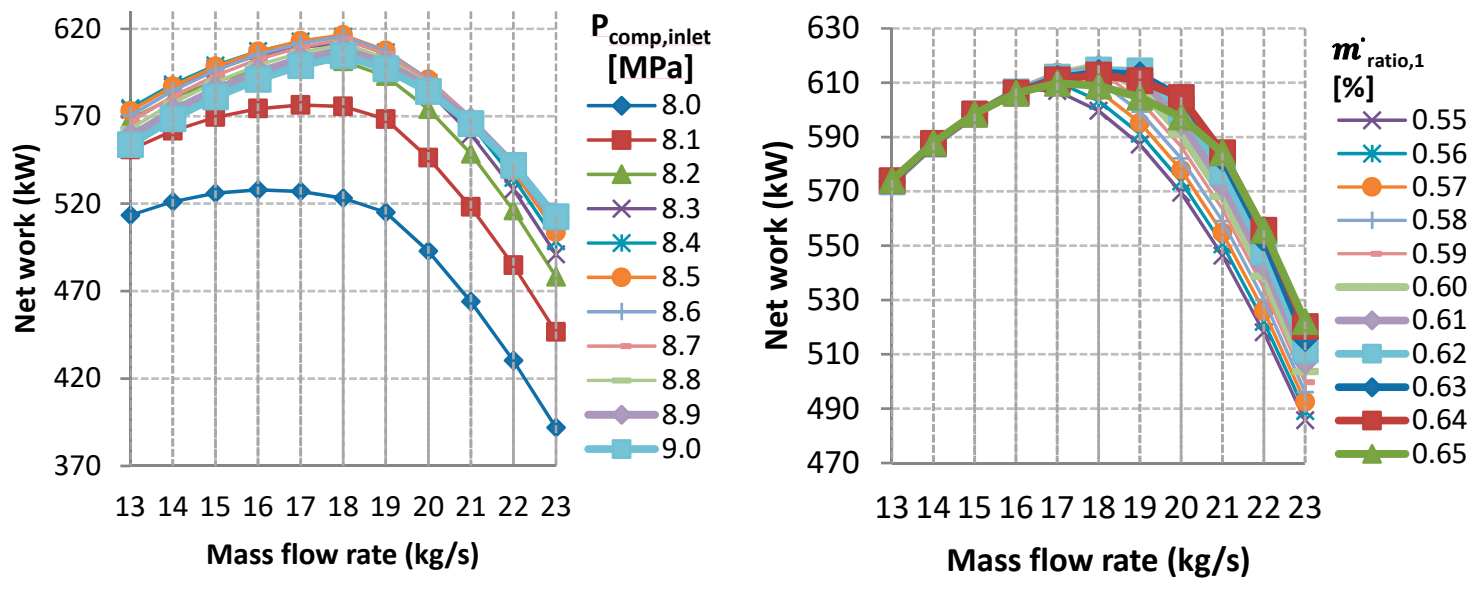

Figure 17. Net work dependence with mass flow rate, flow split, and turbine outlet pressure.

\subsubsection{Modified Partial Heating Cycle with SA Heat}

To increase the cycle performance, the partial heating cycle with SA heat was modified by changing the flow split merging point from cold side inlet to cold side outlet of EG heat exchanger (see Figure 18). It has the same number of heat exchangers and turbomachinery with the partial heating cycle with SA heat.

$W H R I=14.5 \%$

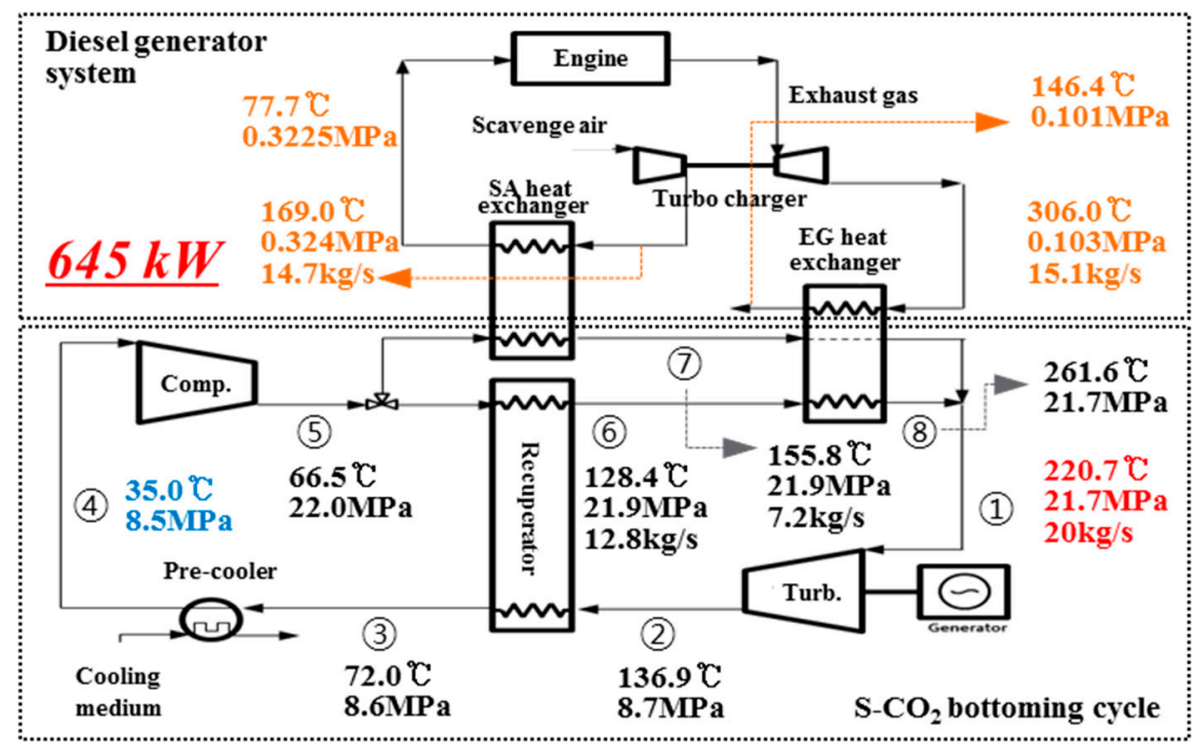

Figure 18. Configuration of modified partial heating cycle with SA heat.

The T-s diagram of the modified partial heating cycle with SA heat for the $\mathrm{S}-\mathrm{CO}_{2}$ bottoming cycle is shown in Figure 19. Figure 20 shows the net produced work dependence on design variables. The modified partial heating cycle with SA heat has 14.5\% WHRI and $645 \mathrm{kWe}$ net produced work which is the $0.8 \%$ and $38 \mathrm{kWe}(+6.3 \%)$ higher than the partial heating cycle. By changing the flow split merging point from cold side inlet to cold side outlet of EG heat exchanger, waste heat recovery is increased from 3.63 MWth to 3.91 MWth (+7.7\%) since the temperature of cold side inlet of EG heat exchanger is decreased. 


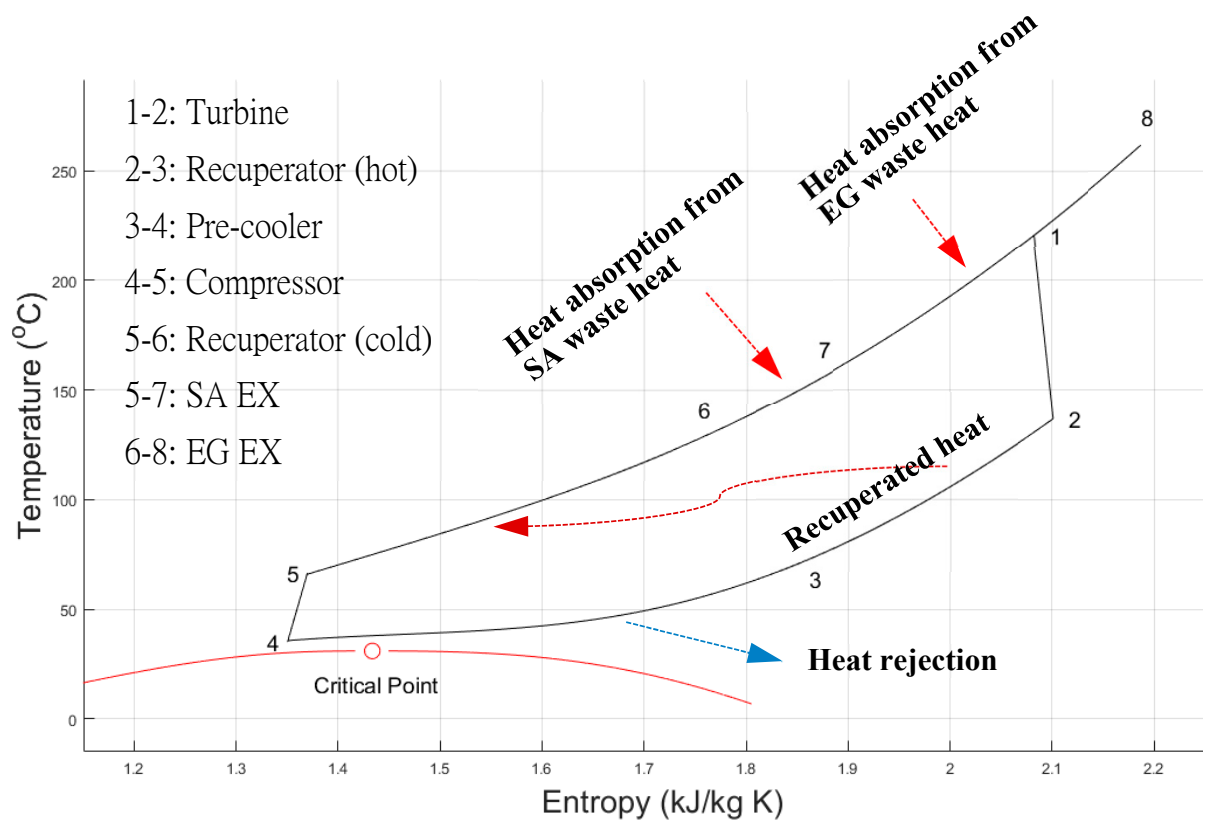

Figure 19. T-s diagram of the modified partial heating cycle with SA heat.

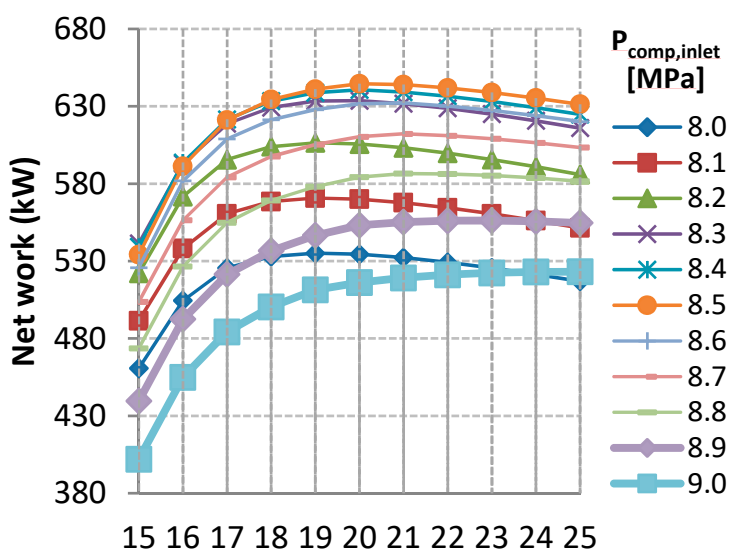

Mass flow rate $(\mathrm{kg} / \mathrm{s})$

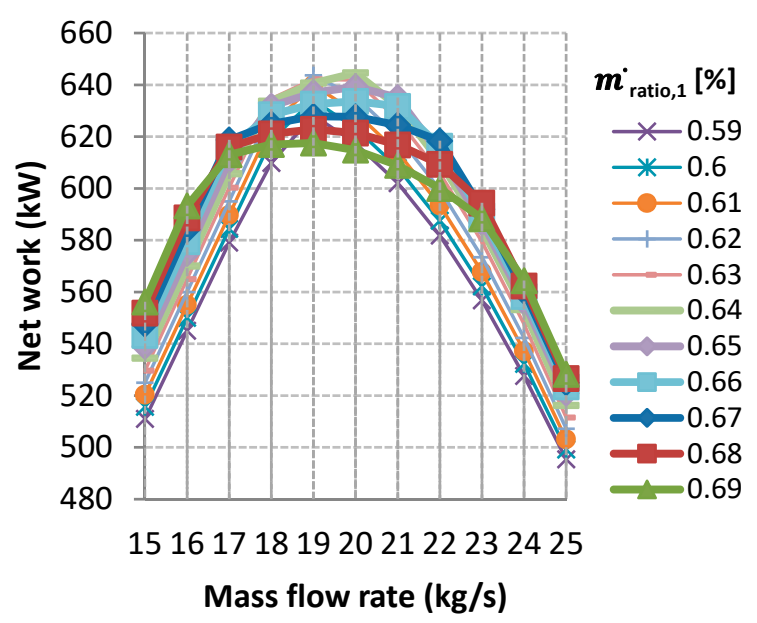

Figure 20. Net work dependence with mass flow rate, flow split, and turbine outlet pressure. 


\section{Discussion and Summary}

Table 9 summarizes the main characteristics of various $\mathrm{S}-\mathrm{CO}_{2}$ cycles for a waste heat recovery of 7.2 MW AAC DG. It is clear from Table 9 that the recompression cycle is not the best cycle to recover waste heat of the DG due to the small temperature difference in the EG and SA heat exchangers. In this study, the net work of the modified partial heating cycle with SA heat achieved $645 \mathrm{kWe}$, which is the highest among the analyzed S- $\mathrm{CO}_{2}$ cycles. Because emission factor considered for a diesel generator was $1.27 \mathrm{~kg}$ of $\mathrm{CO}_{2} / \mathrm{kWh}$ [23], modified partial heating cycle with SA heat can reduce $819.2 \mathrm{~kg}$ of $\mathrm{CO}_{2} / \mathrm{h}$. Having lower values with optimal $\mathrm{CO}_{2}$ mass flow rate, number of components, and total exchanged heat means that the selected cycle has more preferable characteristics compared to the others. Lower $\mathrm{CO}_{2}$ mass flow rate has benefits in pipe cost and pressure drop. Also, lower number of components, and lower total exchanged heat have benefits in CAPEX and OPEX since the system volume is most critical design parameter [24]. Cycle net efficiency, net work and WHRI are the main concerns in system performance and the performance of the modified partial heating cycle with SA heat is to the best among the others. The optimal $\mathrm{CO}_{2}$ mass flow rate of the modified partial heating cycle with SA heat is $20 \mathrm{~kg} / \mathrm{s}$ which is larger than that of the exhaust gas.

Table 9. Main characteristics comparison with $\mathrm{S}-\mathrm{CO}_{2}$ cycles for a bottoming cycle.

\begin{tabular}{|c|c|c|c|c|c|c|c|}
\hline Cycle Layout & $\begin{array}{c}\text { Optimal } \mathrm{CO}_{2} \\
\text { Mass Flow } \\
\text { Rate (kg/s) }\end{array}$ & $\begin{array}{c}\text { Number of } \\
\text { HX/Turb./ } \\
\text { Comp. (-) }\end{array}$ & $\begin{array}{c}\text { Total } \\
\text { Exchanged } \\
\text { Heat } \\
\text { (MWth) }\end{array}$ & $\begin{array}{l}\text { Waste } \\
\text { Heat } \\
\text { Recovery } \\
\text { (MWth) }\end{array}$ & $\begin{array}{l}\text { Cycle Net } \\
\text { Efficiency } \\
(\%)\end{array}$ & $\begin{array}{l}\text { Net } \\
\text { Produced } \\
\text { Work } \\
\text { (kWe) }\end{array}$ & $\begin{array}{l}\text { WHRI } \\
(\%)\end{array}$ \\
\hline (1-1) Simple recuperated cycle & 12 & $3 / 1 / 1$ & 6.23 & 2.55 & 20.20 & 515 & 11.6 \\
\hline $\begin{array}{l}\text { (1-2) Simple recuperation cycle } \\
\text { with SA heat }\end{array}$ & 16 & $4 / 1 / 1$ & 7.58 & 3.21 & 17.67 & 568 & 12.8 \\
\hline $\begin{array}{l}\text { (2-1) Recompression cycle with } \\
\text { SA heat }\end{array}$ & 18 & $5 / 1 / 2$ & 8.29 & 3.45 & 17.65 & 613 & 13.8 \\
\hline (3-1) Partial heating cycle & 16 & $4 / 1 / 1$ & 8.17 & 3.63 & 16.73 & 607 & 13.7 \\
\hline $\begin{array}{l}\text { (3-2) Partial heating cycle with } \\
\text { SA heat }\end{array}$ & 18 & $4 / 1 / 1$ & 8.46 & 3.70 & 16.67 & 616 & 13.9 \\
\hline $\begin{array}{l}\text { (3-3) Modified partial } \\
\text { heating cycle } \\
\text { with SA heat }\end{array}$ & 20 & $4 / 1 / 1$ & 8.99 & 3.91 & 16.47 & 645 & 14.5 \\
\hline
\end{tabular}

\section{Component Design}

\subsection{Turbomachinery Design}

The turbomachinery was designed to arrange components optimally and to conduct the off-design analysis by predicting the performance for the modified partial heating cycle with SA heat. It is generally known that in case of small scale power conversion systems under a few tens of MW level, radial turbomachinery is suitable since the volumetric flow rate of working fluid is relatively low enough to use axial turbomachinery. Argonne National Laboratory (ANL) has suggested suitable design choices for designing $\mathrm{S}-\mathrm{CO}_{2}$ turbomachinery. The ANL also presented that small scale turbomachinery of $\mathrm{S}-\mathrm{CO}_{2}$ system is better to design with radial type [25]. Therefore, the radial type turbomachinery was selected for component design of the modified partial heating cycle with SA heat.

In this turbomachinery design study, the Balje's diagram known as the most useful turbomachinery preliminary design method was utilized for the design prediction [26]. The base parameters of turbomachinery design can be easily obtained with the specific speed $\left(n_{s}\right)$ and diameter $\left(d_{s}\right)$ since Balje's diagram suggests optimal values. Additionally, it represents the efficiency of turbomachinery depends on specific speed as shown in Figure 21. Table 10 shows the turbomachinery design results such as stages, impeller diameter and rotational speed for the designed operating condition by using the Balje's diagram with the non-dimensional numbers. 


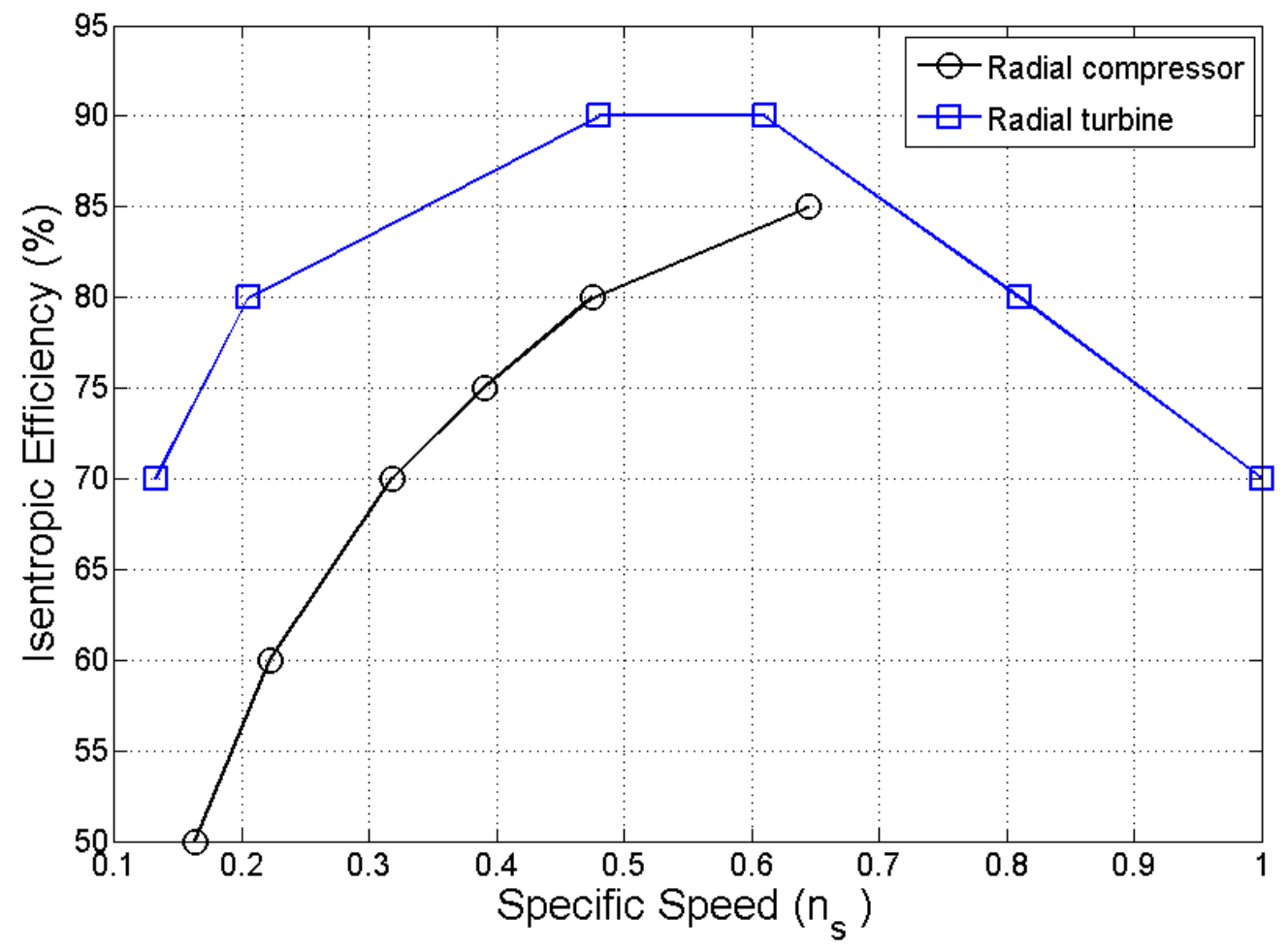

Figure 21. Efficiency variation with specific speed (recreation of figure in Ref. [26]).

Table 10. Turbomachinery design of the modified partial heating cycle with SA heat.

\begin{tabular}{cccccccc}
\hline \multicolumn{7}{c}{ Type: Radial } \\
\hline $\begin{array}{c}\text { Mass flow rate } \\
(\mathrm{kg} / \mathrm{s})\end{array}$ & Stages & $\begin{array}{c}\text { Diameter } \\
(\mathrm{m})\end{array}$ & $\begin{array}{c}\text { Specific } \\
\text { Speed }\end{array}$ & $\begin{array}{c}\text { Specific } \\
\text { diameter }\end{array}$ & $\begin{array}{c}\text { Efficiency } \\
(\%)\end{array}$ & RPM \\
\hline Turbine & 20 & 1 & 0.1 & 0.54 & 4.33 & 88 & 56,000 \\
\hline Compressor & 20 & 1 & 0.07 & 0.63 & 4.62 & 75 & 56,000 \\
\hline
\end{tabular}

The specific speed and diameter:

$$
n_{s}=\frac{\omega \sqrt{V_{1}}}{\left(g H_{a d}\right)^{3 / 4}}, \quad d_{s}=\frac{D\left(g H_{a d}\right)^{1 / 4}}{\sqrt{V_{1}}}
$$

The performance maps prediction was obtained with the in-house code KAIST-Turbomachinery Design (KAIST-TMD [27]. The turbomachinery design method of the KAIST-TMD code is a one dimensional mean-line analysis including a real gas approach for overcoming the limitation of conventional turbomachinery design tools near the $\mathrm{S}-\mathrm{CO}_{2}$ critical point. The reliability of the $1 \mathrm{D}$ turbomachinery code depends on choice of loss models. The loss model combination for radial compressor was validated with S- $\mathrm{CO}_{2}$ compressor test data [28]. However, due to the lack of S- $\mathrm{CO}_{2}$ turbine test data, the loss model combination for radial turbine was validated with test data of air radial turbine. Although S- $\mathrm{CO}_{2}$ has a higher Reynolds number than air, it is acceptable to utilize air turbine data as an alternative, because the effect on turbine performance can be ignored over half a million in Reynolds number and $\mathrm{S}-\mathrm{CO}_{2}$ behaves like ideal gas in turbine operation range [29]. The performance map results such as pressure ratio and efficiency of the turbomachinery for the modified partial heating cycle with SA heat was calculated using the KAIST-TMD code and are shown in Figures 22-25. 


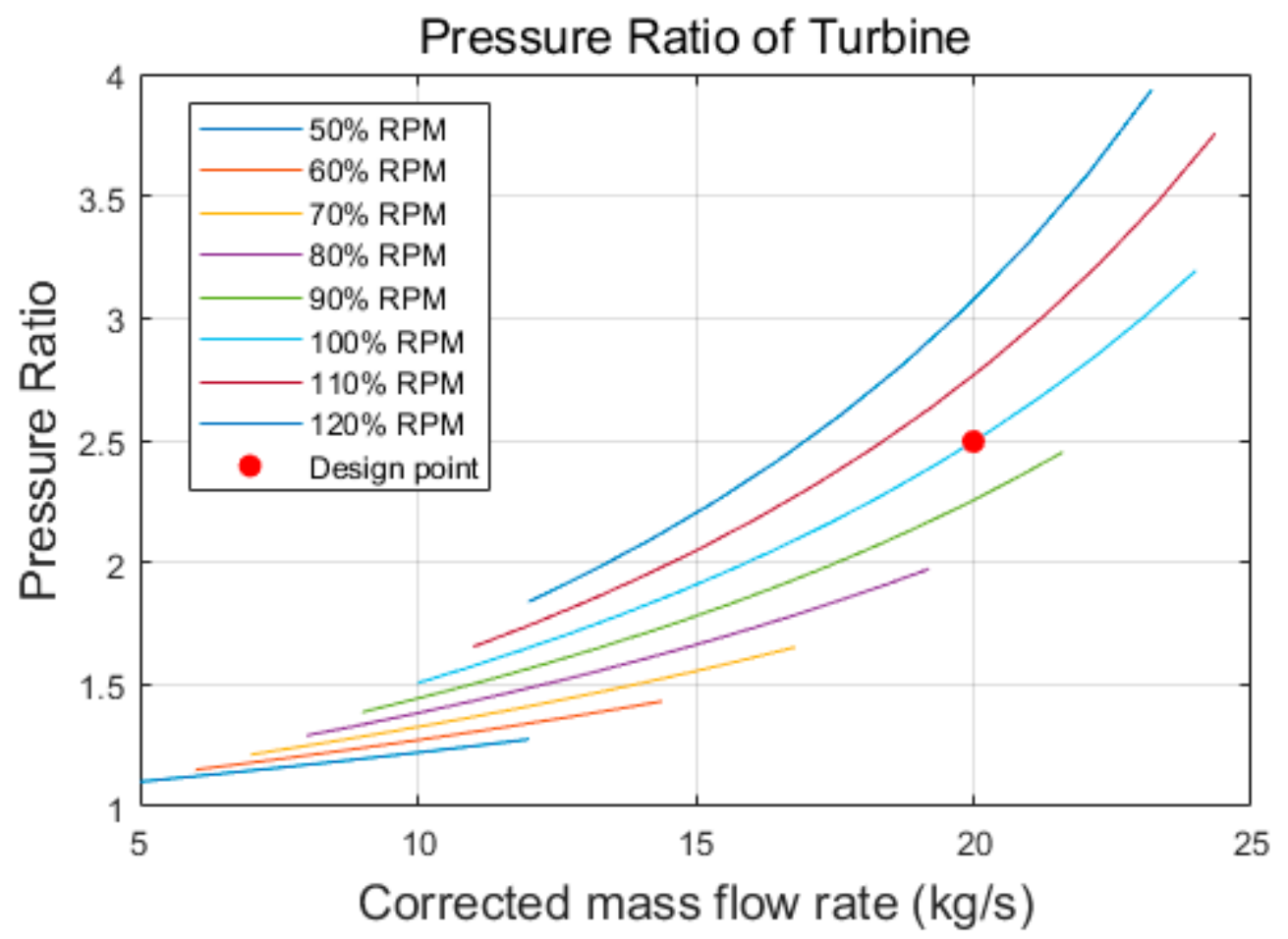

Figure 22. Turbine pressure ratio performance map of the modified partial heating cycle with SA heat.

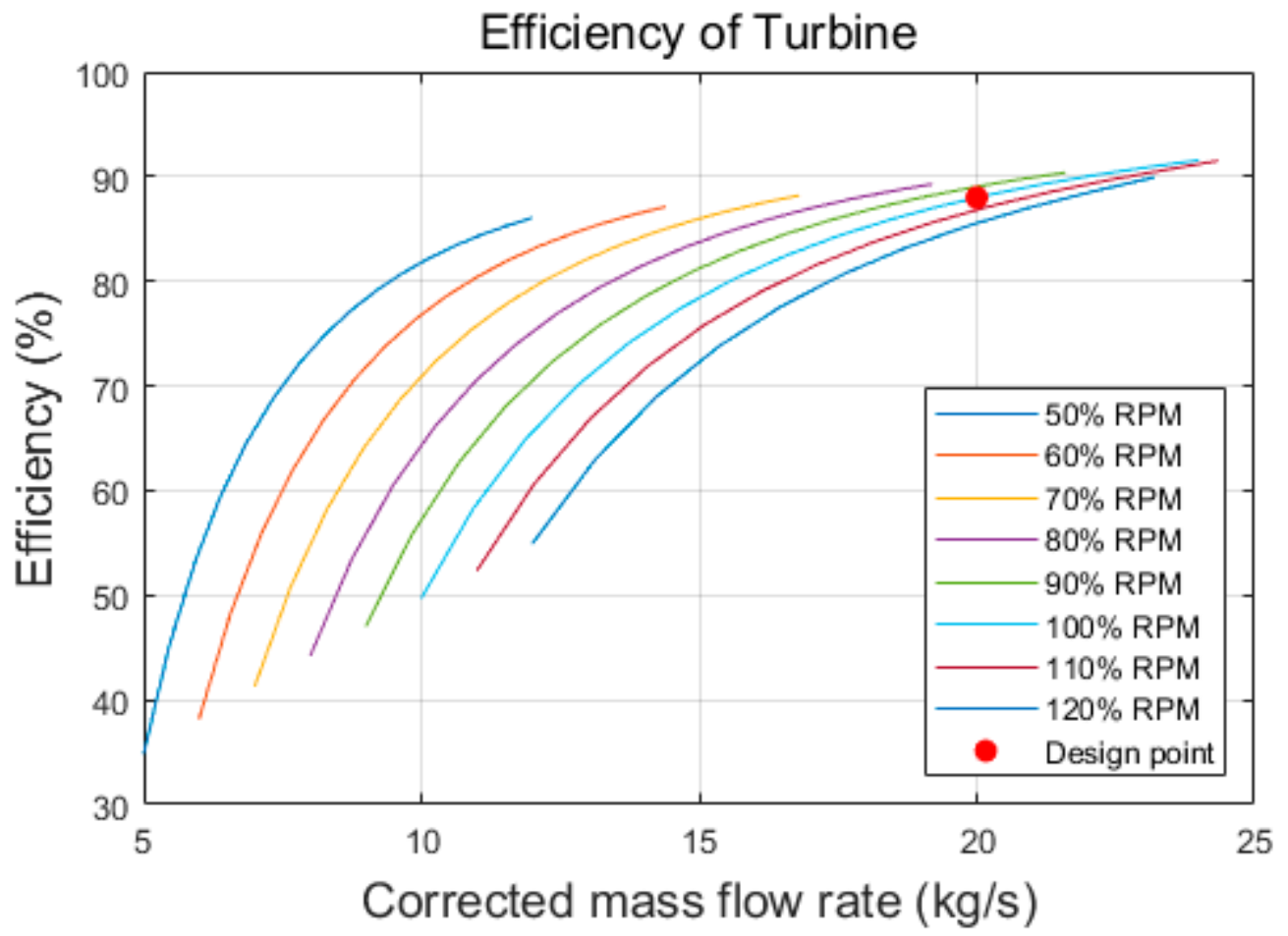

Figure 23. Turbine efficiency performance map of the modified partial heating cycle with SA heat. 


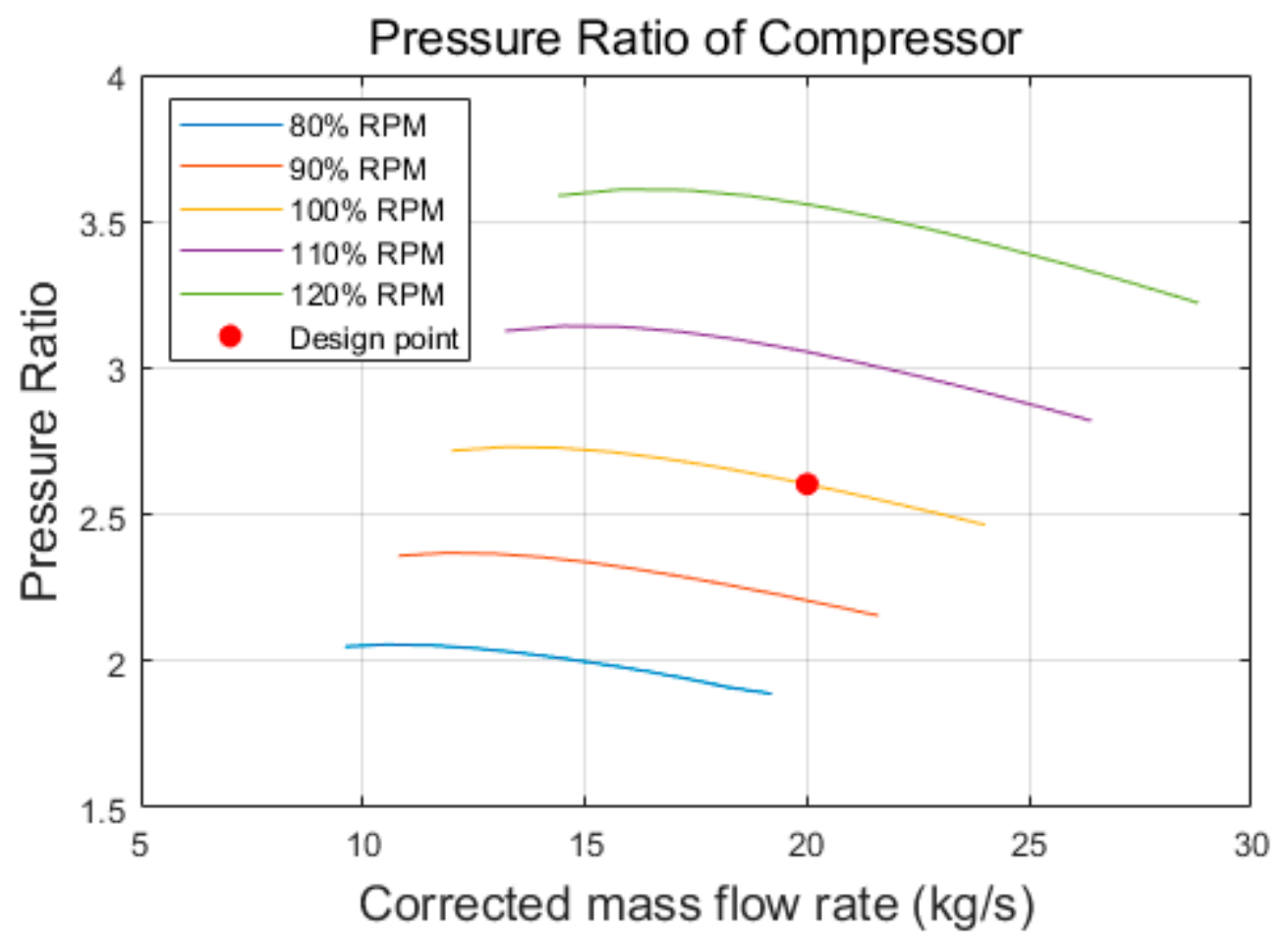

Figure 24. Compressor pressure ratio performance map of the modified partial heating cycle with SA heat.

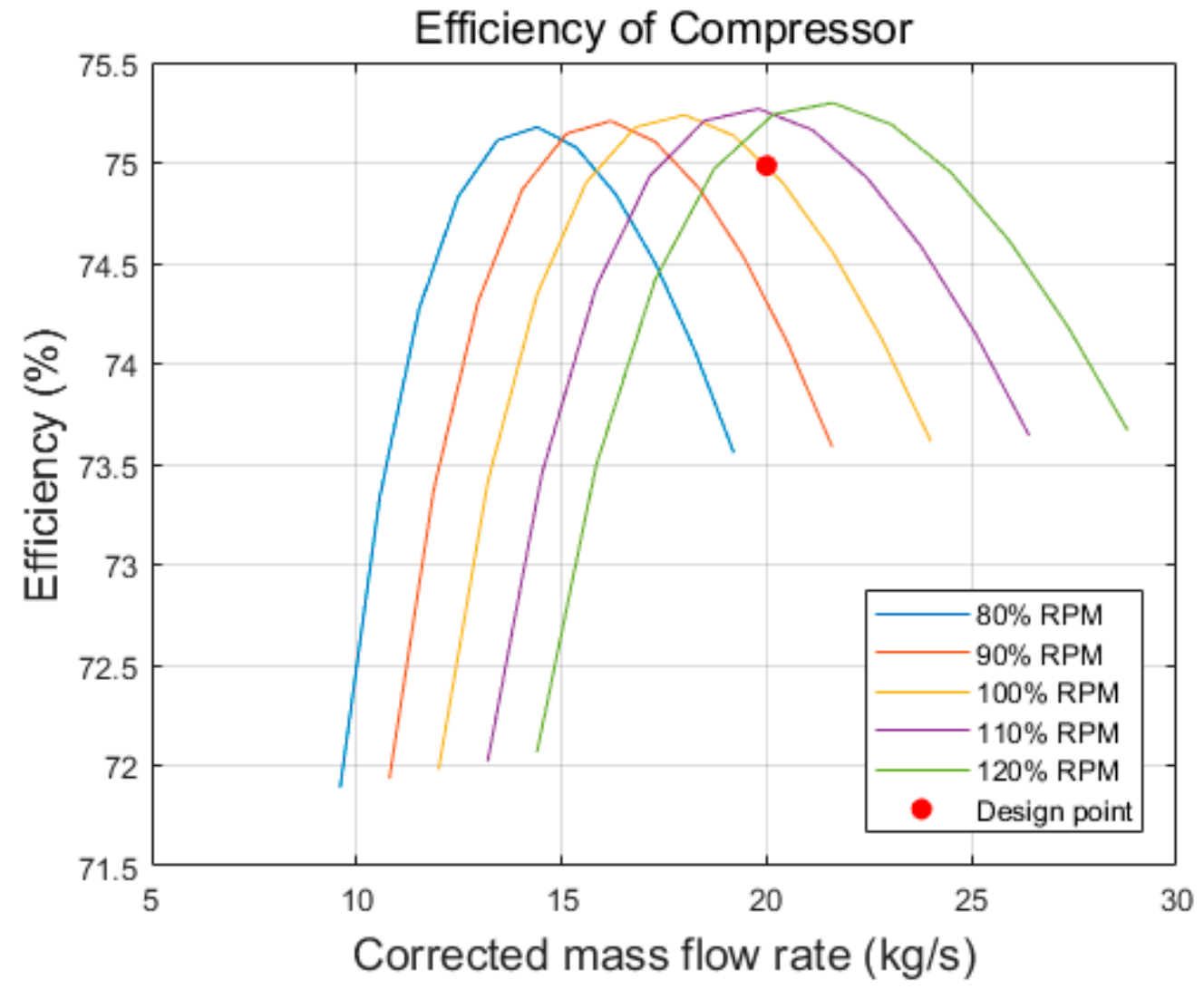

Figure 25. Compressor efficiency performance map of the modified partial heating cycle with SA heat. 


\subsection{Heat Exchanger Design}

As previously mentioned in this paper, the main advantages of the $\mathrm{S}-\mathrm{CO}_{2}$ cycle are that it helps arrange the system in a compact way. It is well known that the overall footprint of the $\mathrm{S}-\mathrm{CO}_{2}$ system is directly related to the heat exchanger sizes among major components of the system because the turbomachinery size of the $\mathrm{S}-\mathrm{CO}_{2}$ system is significantly smaller than the heat exchanger size.

In this study, all heat exchangers of the modified partial heating cycle with SA heat are designed while assuming that the heat exchanger type is the Printed Circuit Heat Exchanger (PCHE). PCHE is selected to take full benefits such as high surface to volume density, wide operational range of pressure and temperature over $30 \mathrm{MPa}$ and $800{ }^{\circ} \mathrm{C}$, respectively [30].

In order to design heat exchangers of the cycle, an in-house PCHE design code, KAIST Heat eXchanger Design (KAIST-HXD) is used. Particularly the KAIST-HXD was developed to evaluate the geometry of the heat exchangers that meets requirements such as heat exchanger effectiveness and pressure drop values [31]. All the heat exchangers were designed with the configuration of a counter current flow and the optimal design conditions were also calculated to obtain the minimum volume while satisfying the target performance requirements. Table 11 summarizes the design result of the heat exchangers and Figure 26 shows the temperature profile in the recuperator.

Table 11. Heat exchanger design of the modified partial heating cycle with SA heat.

\begin{tabular}{ccc}
\hline Parameter. & Pre-Cooler & Recuperator \\
\hline Type & PCHE & PCHE \\
\hline Shape & Zig-zag flow channel & Zig-zag flow channel \\
\hline Hot channel fluid & $\mathrm{CO}_{2}$ & $\mathrm{CO}_{2}$ \\
\hline Cold channel fluid & Water & $\mathrm{CO}_{2}$ \\
\hline Hot channel D (semi-circular) & $2.0 \mathrm{~mm}$ & $2 \mathrm{~mm}$ \\
\hline Cold channel D (semi-circular) & $2.0 \mathrm{~mm}$ & $1.8 \mathrm{~mm}$ \\
\hline Hot channel No & 8500 & 135,000 \\
\hline Cold channel No & 8500 & 6750 \\
\hline Hot side Re \# (Avg) & 70,215 & 54,602 \\
\hline Cold side Re \# (Avg) & 5008 & 37,820 \\
\hline Length & $0.78 \mathrm{~m}$ & $0.96 \mathrm{~m}$ \\
\hline Volume & $0.088 \mathrm{~m}^{3}$ & $0.12389 \mathrm{~m}^{3}$ \\
\hline Pinch point & $6.1{ }^{\circ} \mathrm{C}$ & $4.97{ }^{\circ} \mathrm{C}$ \\
\hline
\end{tabular}

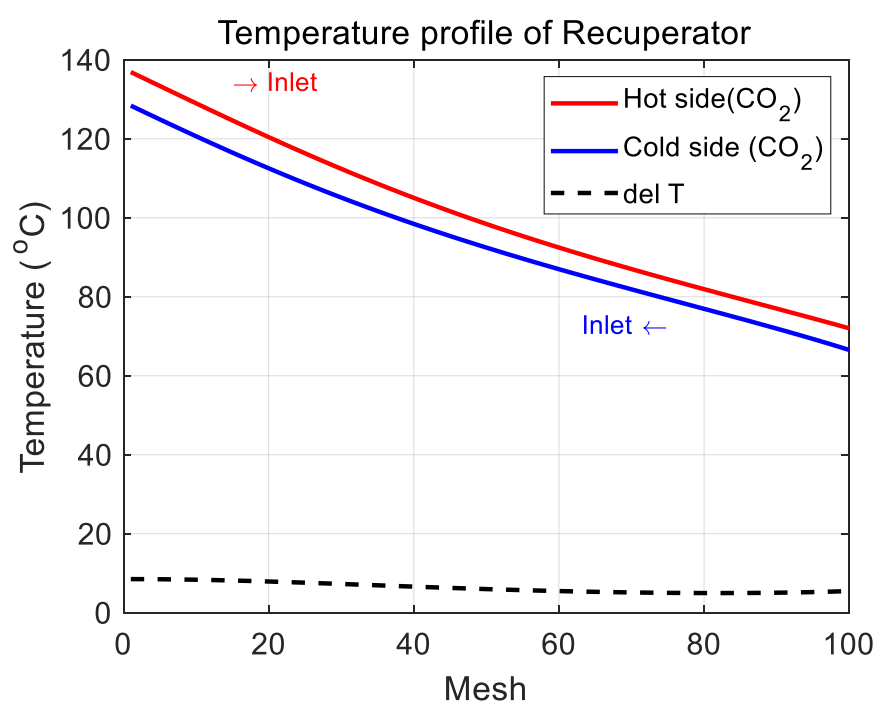

Figure 26. Temperature profile of the designed recuperator. 


\section{Off-Design Analysis}

\section{Quasi-Steady State Analysis}

To establish the control logic for the part-load operation, an in-house quasi-static cycle analysis code, KAIST-QCD (Quasi-static Cycle Design) was developed by a KAIST research team [32]. In the system performance analysis, various factors influence the system behavior. Quasi-steady state is defined as a pseudo steady state of the system and the analysis method is applied when the off-design performance of the system is important but the transient performance is less of an interest. The quasi-steady state analysis provides quick and simple solutions that describe each operating condition in the system. Compared to the transient analysis, the quasi-steady state analysis requires less calculation time and provides useful information for designing control schemes for the system.

In this paper, the component design parameters of compressors, turbines and, heat exchangers described previously are used for the quasi-steady state analysis. During the quasi-steady state analysis, compressor inlet condition is first defined. Compressor performance is affected by two factors: the compressor inlet condition and the rotating speed. Based on turbine and compressor off-design performance maps, mass flow in the system is calculated. After that, heat loads between hot and cold side of heat exchangers are calculated. The algorithm of quasi-steady state analysis is shown in Figure 27. In this scenario, it is assumed that only mass inventory control was applied, and RPM was kept at design value for grid stability.

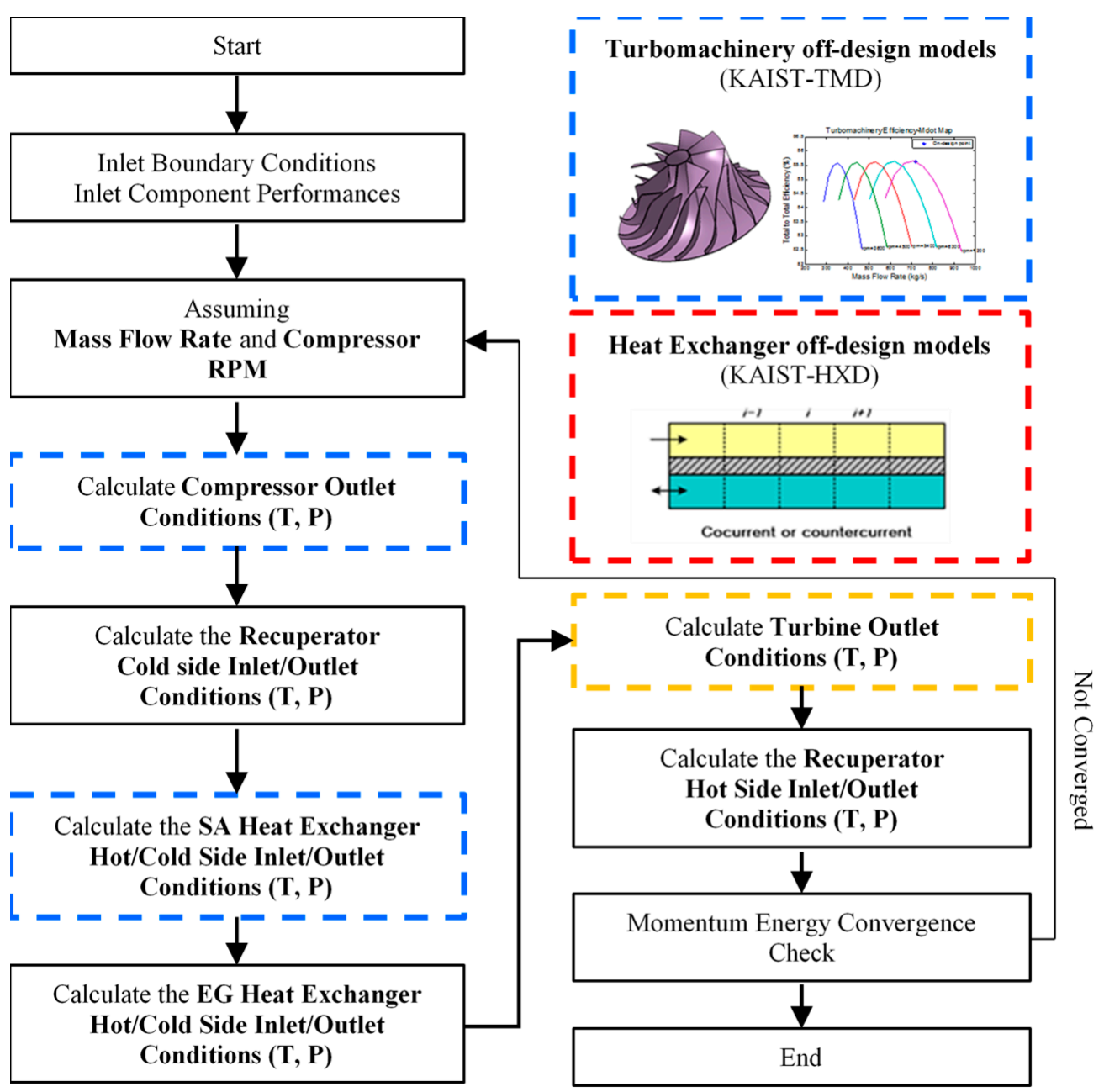

Figure 27. S- $\mathrm{CO}_{2}$ cycle quasi-steady state analysis code algorithm. 
Off-design performance of a waste heat recovery system at 63,94 , and $100 \%$ thermal load, respectively, is shown in Figures 28-30. As shown in figures, as the load increases, the optimum points are formed at larger system flow rates and larger flow split ratio to the SA heat exchanger $\left(\dot{m}_{\text {ratio }}\right)$. This means that the lower the thermal load, the higher the performance can be achieved when controlled to reduce the flow to the SA heat exchanger. These results show an output difference of as much as $100 \mathrm{~kW}$ or more between the optimal and non-optimal points. Therefore, it is necessary to further study the strategy of controlling the driving point to be followed by producing the optimal driving point according to each off-design operation mode in advance. The performance change of off-design optimum point according to thermal load is shown in Figure 31. A loss of $6.74 \mathrm{~kW}$ net-work is expected for $1 \%$ p thermal load decrease.

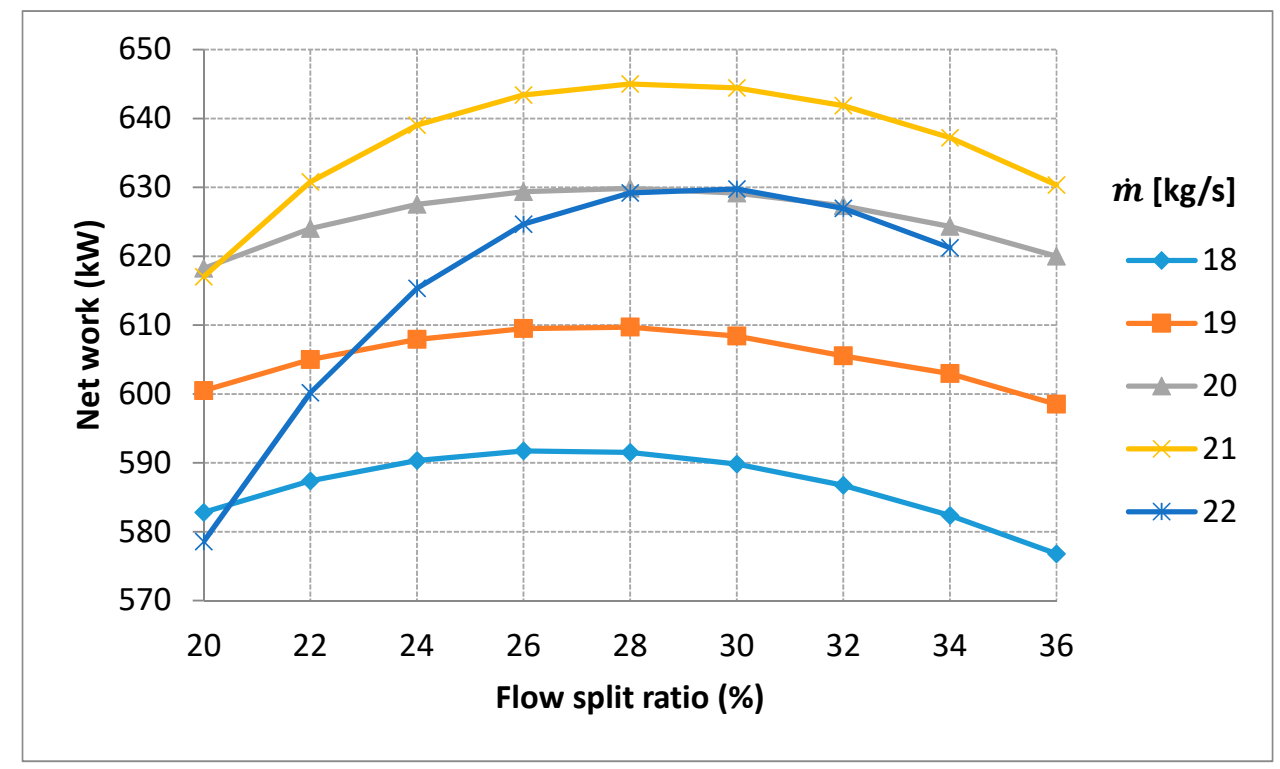

Figure 28. Quasi-steady state analysis result (100\% load).

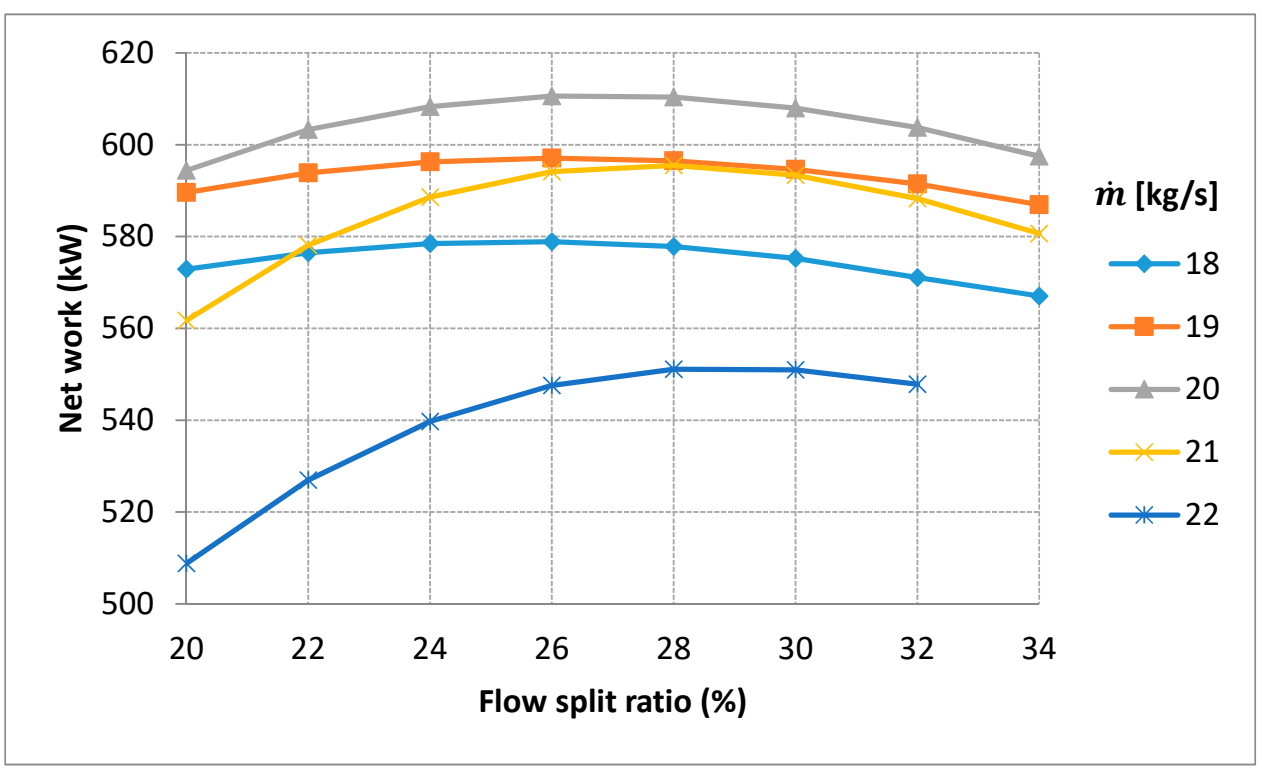

Figure 29. Quasi-steady state analysis result (94\% load). 


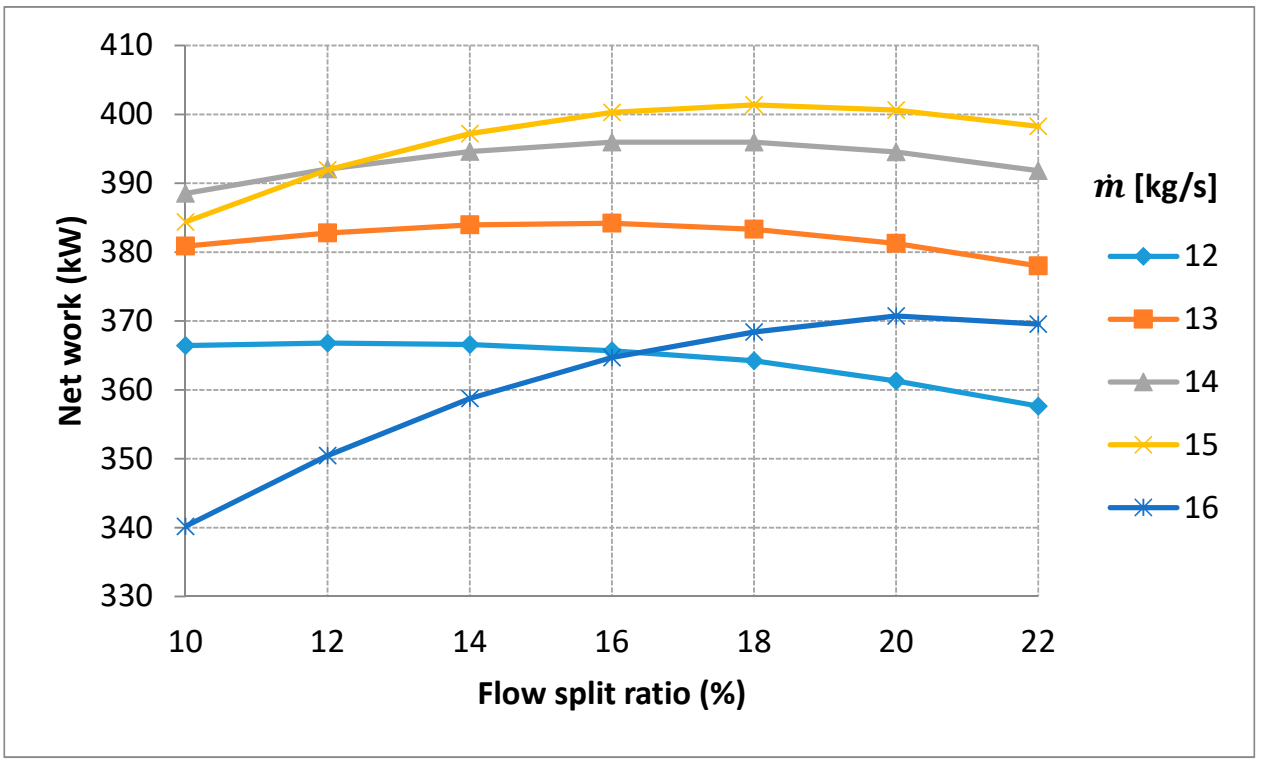

Figure 30. Quasi-steady state analysis result (63\% load).

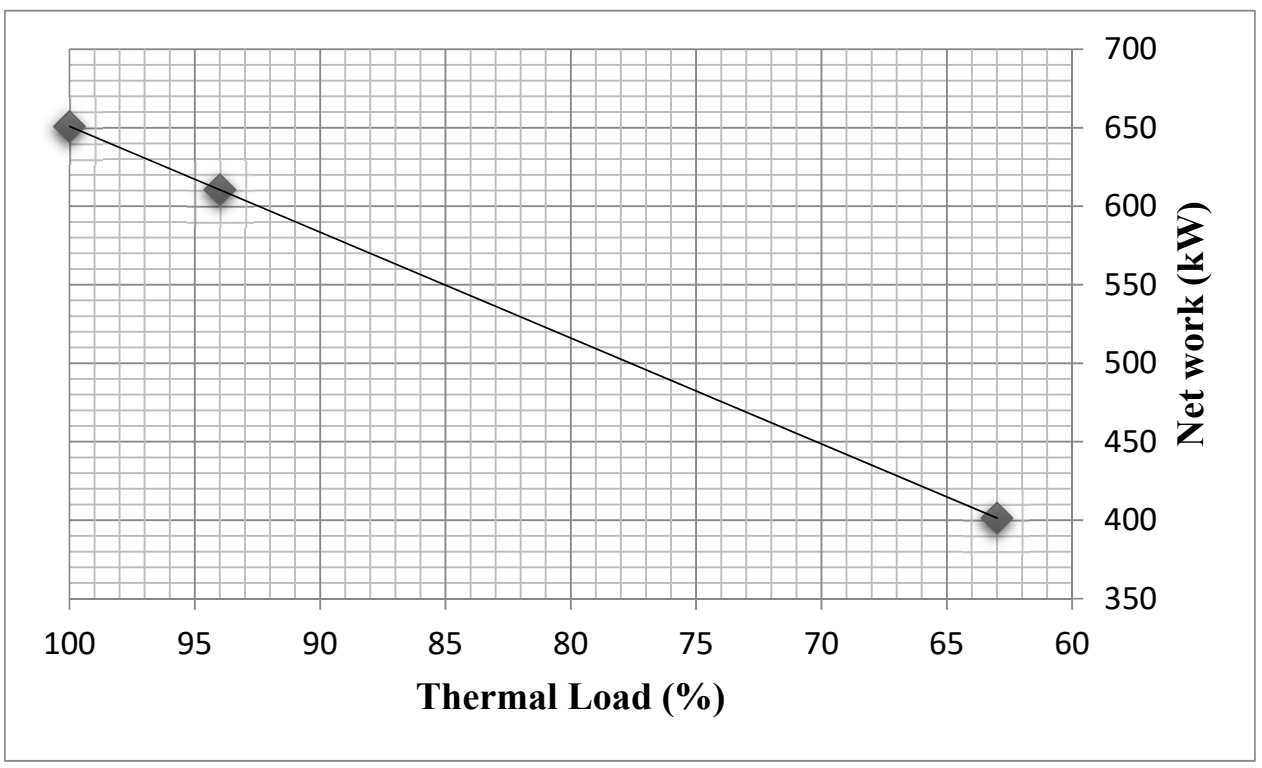

Figure 31. S- $\mathrm{CO}_{2}$ cycle performance in part load conditions.

\section{Conclusions}

In this paper, results of the thermodynamic cycle analyses and sensitivity analyses of various $\mathrm{S}-\mathrm{CO}_{2}$ cycles for the waste heat recovery of a 7.2 MW diesel engine used in a nuclear power plant are presented. The diesel engine can provide two heat sources for the waste heat recovery system: one from exhaust gas and the other from scavenge air. This is unique compared to other heat sources such as fossil fuel power plants, concentrated solar power systems, nuclear power plants, etc. Thus, it was necessary to review the $\mathrm{S}-\mathrm{CO}_{2}$ cycle layouts for dual heat sources application.

As a result of cycle comparisons, it was found that the partial heating cycle produces the highest net work while having a simple layout and small number of major components. Particularly, the partial heating cycle has additional advantage in respect of easier cycle operation scheme since it requires single turbine and compressor only.

Furthermore, the partial heating cycle was modified by changing the flow split merging point from cold side inlet to cold side outlet of exhaust gas heat exchanger, to additionally use the scavenge 
air heat from diesel engine turbocharger. The waste heat recovery is sharply increased by applying dual heat sources from exhaust gas and scavenge air. This study identified that waste heat recovery can be increased more by changing the flow split merging point of a partial heating cycle for the diesel engine application.

The main components, including turbomachinery and heat exchangers, are designed with in-house codes which have been validated with experiment data. Based on the designed cycle and components, the $\mathrm{S}-\mathrm{CO}_{2}$ cycle performance under partial load conditions is analyzed with an in-house quasi-steady state cycle analysis code to find the optimal operating condition and to establish the control logic for the part-load operation. In this paper, part-load operation and optimal operating conditions were calculated varying from $63-100 \%$. For the off-design analysis it is performed while assuming only mass inventory control is applied. RPM was kept at design value for the grid stability. Part load analysis shows an output difference of as much as $100 \mathrm{~kW}$ or more between the optimal and non-optimal points. Therefore, it is necessary to further study the strategy of controlling the operation point for each off-design operation mode. Moreover, the performance change of off-design optimum point for varying thermal load is important for economic analysis of the system.

The additional power from the AAC DG waste heat recovery system can operate a nuclear safety system without revising the existing nuclear power plant's layout too much. By producing additional $645 \mathrm{kWe}$ from the S-CO $\mathrm{CO}_{2}$ bottoming cycle from $3 \mathrm{MWth}$ waste heat, nuclear safety can be improved by potentially extending AAC DG operation time or adopting more safety components to improve redundancy or diversity. Furthermore, more instrument and control systems can be utilized during accident from the additional power of the waste heat recovery system.

Author Contributions: Conceptualization, J.K.H.; Methodology, J.K.H. and M.S.K.; Software, J.K.H., M.S.K. and S.S.; Validation, J.K.H., M.S.K. and J.L.; Formal Analysis, J.K.H. and M.S.K.; Investigation, B.S.O.; Resources, J.L.; Data Curation, S.S.; Writing-Original Draft Preparation, J.K.H.; Writing-Review \& Editing, J.I.L.; Visualization, M.S.K.; Supervision, J.I.L.; Project Administration, J.I.L.; Funding Acquisition, J.I.L.

Funding: This work was supported by the National Research Foundation of Korea (NRF) grant funded by the Korea government (MSIP) (2017M2B2B1071971).

Acknowledgments: This work was supported by the National Research Foundation of Korea (NRF) grant funded by the Korea government (MSIP) (2017M2B2B1071971).

Conflicts of Interest: The authors declare no conflict of interest.

\section{Nomenclature}

$\begin{array}{ll}\eta: & \text { efficiency } \\ \dot{m}: & \text { mass flow rate } \\ h: & \text { enthalpy } \\ T: & \text { temperature } \\ P: & \text { pressure } \\ s: & \text { entropy } \\ W: & \text { work } \\ P_{\text {comp }, \text { inlet }}: & \text { compressor inlet pressure } \\ \dot{m}_{\text {ratio }}: & \text { flow split ratio } \\ c_{p}: & \text { specific heat capacity } \\ \rho: & \text { fluid density } \\ \omega: & \text { the angular frequency of the rotor } \\ V: & \text { velocity } \\ g: & \text { gravity force acceleration } \\ H: & \text { head } \\ D: & \text { diameter } \\ n_{s}: & \text { specific speed } \\ d_{s}: & \text { specific diameter }\end{array}$




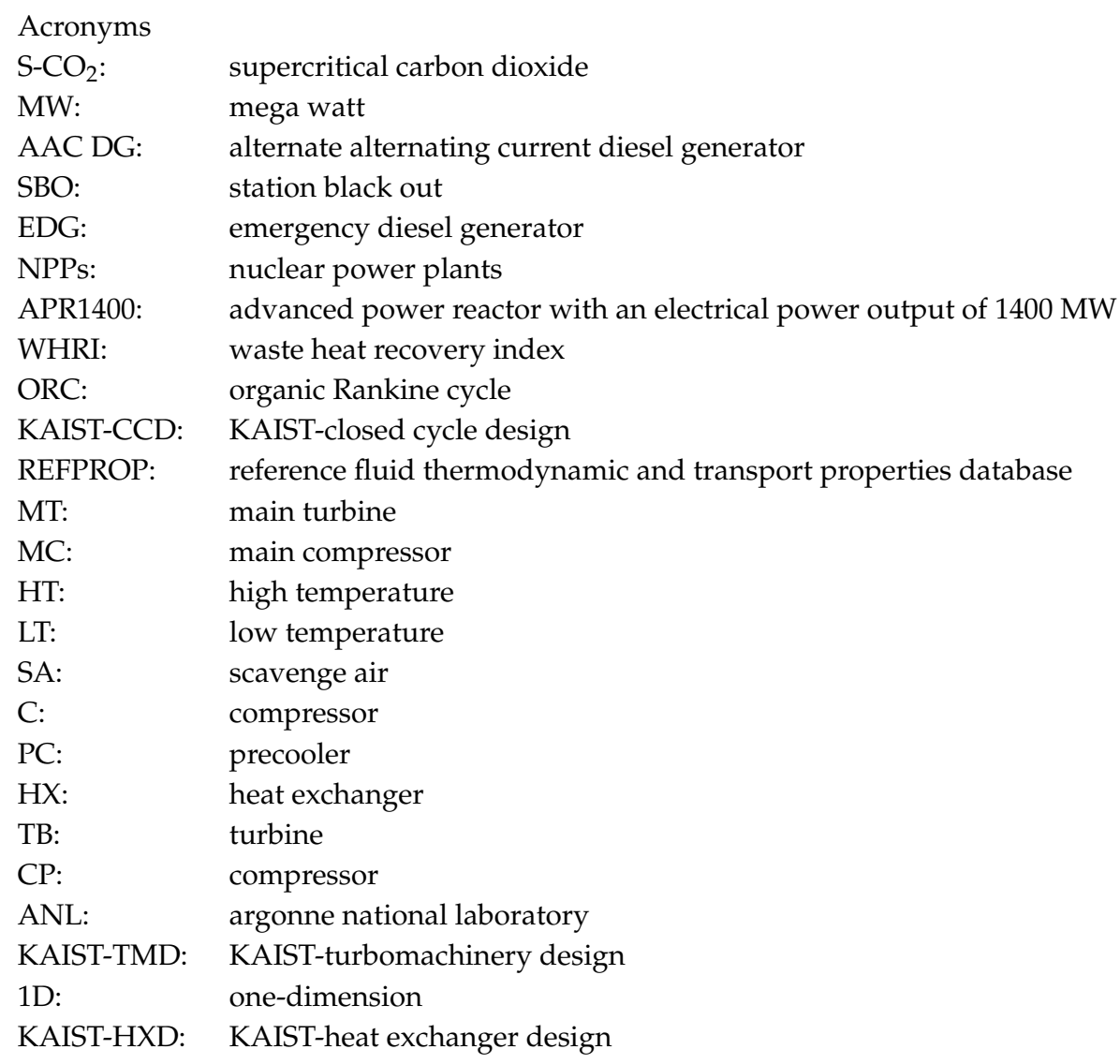

\section{References}

1. Kim, B.K.; Jeong, B.S.; Jo, M.K. Post-Fukushima Action Plan in Korea; Oxford Christ Church: Oxford, UK, 2011.

2. Emirates Nuclear Energy Corporation. BRAKA Nuclear Power Plant Units $1 \mathcal{E} 2$ Preliminary Safety Analysis Report; Emirates Nuclear Energy Corporation: Abu Dhabi, UAE, 2010.

3. Lee, S.K. Development Status of Emergency Diesel Generator Status Diagnosis in Nuclear Power Plants. J. Electr. World 2014, Special And+, 82-88.

4. Dostal, V.; Hejzlar, P.; Driscoll, M.J. The supercritical carbon dioxide power cycle: Comparison to other advanced power cycles. Nucl. Technol. 2006, 154, 283-301. [CrossRef]

5. Chen, Y.; Lundqvist, P.; Johansson, A.; Platell, P. A comparative study of the carbon dioxide transcritical power cycle compared with an organic rankine cycle with R123 as working fluid in waste heat recovery. Appl. Therm. Eng. 2006, 26, 2142-2147. [CrossRef]

6. Yoon, H.J.; Ahn, Y.; Lee, J.I.; Addad, Y. Potential advantages of coupling supercritical $\mathrm{CO}_{2}$ Brayton cycle to water cooled small and medium size reactor. Nucl. Eng. Des. 2012, 245, 223-232. [CrossRef]

7. Feher, E.G. Supercritical thermodynamic power cycle, presented to the IECEC. Douglas Paper, 2 August 1967; p. 4348.

8. Bae, S.J.; Lee, J.; Ahn, Y.; Lee, J.I. Preliminary studies of compact Brayton cycle performance for small modular high temperature gas-cooled reactor system. Ann. Nucl. Energy 2015, 75, 11-19. [CrossRef]

9. Martelli, E.; Nord, L.; Bolland, O. Design criteria and optimization of heat recovery steam cycles for integrated reforming combined cycles with $\mathrm{CO}_{2}$ capture. Appl. Energy 2012, 92, 255-268. [CrossRef]

10. Heo, J.Y.; Kim, M.S.; Baik, S.; Bae, S.J.; Lee, J.I. Thermodynamic study of supercritical $\mathrm{CO}_{2}$ Brayton cycle using an isothermal compressor. Appl. Energy 2017, 206, 1118-1130. [CrossRef]

11. Ahn, Y.; Lee, J.; Kim, S.G.; Lee, J.I.; Cha, J.E. The design study of supercriticalcarbon dioxide integral experiment loop. In Proceedings of the ASME Turbo Expo 2013: Turbine Technical Conference and Exposition, San Antonio, TX, USA, 3-7 June 2013. 
12. Cho, S.K.; Kim, M.; Baik, S.; Ahn, Y.; Lee, J.I. Investigation of the bottoming cycle for high efficiency combined cycle gas turbine system with supercritical carbon dioxide power cycle. In Proceedings of the ASME Turbo Expo 2015: Turbine Technical Conference and Exposition, Montreal, QC, Canada, 15-19 June 2015.

13. Kim, M.S.; Ahn, Y.; Kim, B.; Lee, J.I. Study on the supercritical $\mathrm{CO}_{2}$ power cycles for landfill gas firing gas turbine bottoming cycle. Energy 2016, 111, 893-909. [CrossRef]

14. Lemmon, E.W.; Huber, M.L.; McLinden, M.O. NIST Standard Reference Database 23: NIST Reference fluid Thermodynamic and Transport Properties-REFPROP, Version 9.0; National Institute of Standards and Technology: Gaithersburg, DC, USA, 2010.

15. Pavri, R.; Moore, G.D. Gas Turbine Emissions and Control; GE Power Systems: Atlanta, GA, USA, 2001.

16. Cziesla, F.; Bewerunge, J.; Senzel, A. Lünen e state-of-the art ultra supercritical steam power plant under construction. In Proceedings of the POWER-GEN Europe 2009, Cologen, Germany, 26-29 May 2009.

17. Kimzey, G. Development of a brayton bottoming cycle using supercritical carbon dioxide as the working fluid, a report submitted in partial fulfillment of the requirements for gas turbine industrial fellowship. In University Turbine Systems Research Program; Electric Power Research Institute: Palo Alto, CA, USA, 2012.

18. Musgrove, G.O.; Pittaway, C.; Vollnogle, E.; Chordia, L. Tutorial: Heat exchangers for supercritical $\mathrm{CO}_{2}$ power cycle applications. In Proceedings of the 5th International Symposium-Supercritical $\mathrm{CO}_{2} \mathrm{Power}$ Cycles, San Antonio, TX, USA, 28-31 March 2016.

19. Bae, S.J.; Lee, J.I.; Ahn, Y.H.; Lee, J.K. Various supercritical carbon dioxide cycle layouts study for molten carbonate fuel cell application. J. Power Sources 2014, 270, 608-618. [CrossRef]

20. Ahn, Y.H.; Lee, J.I. Study of various brayton cycle designs for small modular sodium-cooled fast reactor. Nucl. Eng. Des. 2014, 276, 128-141. [CrossRef]

21. Kulhanek, M.; Dostal, V. Thermodynamic analysis and comparison of supercritical carbon dioxide cycles. In Proceedings of the Supercritical CO 2 Power Cycle Symposium, Boulder, CO, USA, 24-25 May 2011.

22. Campanari, S.; Macchi, E. Thermodynamic analysis of advanced power cycles based upon solid oxide fuel cells, gas turbines and rankine bottoming cycles, 98-GT-585. In Proceedings of the ASME International Gas Turbine and Aero engine Congress and Exhibition, Stockholm, Sweden, 2-5 June 1998.

23. Jakhrani, A.Q.; Othman, A.; Rigit, A.R.H.; Samo, S.R. Estimation of carbon footprints from diesel generator emissions. In Proceedings of the International Conference Green Ubiquitous Technology, Jakarta, Indonesia, 7-8 July 2012.

24. Hewitt, C.H.; Pugh, S.J. Approximate design and costing methods for heat exchangers. Heat Transf. Eng. 2007, 28, 76-86. [CrossRef]

25. Sienicki, J.J.; Moisseytsev, A.; Fuller, R.; Wright, S.; Pickard, P. Scale Dependencies of Supercritical Carbon Dioxide Brayton Cycle Technologies and Optimal Size for a Next-Step Supercritical $\mathrm{CO}_{2}$ Cycle Demonstration. In Proceedings of the Supercritical CO 2 Power Cycle Symposium, Boulder, CO, USA, 24-25 May 2011.

26. Balje, O.E. Turbomachines: A Guide to Design, Selection, and Theory; A Wiley-Interscience Publication: New York, NY, USA, 1980.

27. Lee, J.; Lee, J.I.; Yoon, H.J.; Jae, E.C. Supercritical Carbon Dioxide turbomachinery design for water-cooled Small Modular Reactor application. Nucl. Eng. Des. 2017, 270, 76-89. [CrossRef]

28. Lee, J.; Cho, S.; Lee, J.I. The Effect of Real Gas Approximations on S-CO $\mathrm{CO}_{2}$ Compressor Design. J. Turbomach. 2018, 140. [CrossRef]

29. Cho, S.K.; Lee, J.; Lee, J.I.; Cha, J.E. S-CO $\mathrm{CO}_{2}$ turbine design for decay heat removal system of sodium cooled fast reactor. In Proceedings of the ASME Turbo Expo 2016: Turbomachinery Technical Conference and Exposition, Seoul, Korea, 13-17 June 2016.

30. Shah, R.K.; Sekulic, D.P. Fundamentals of Heat Exchanger; John Wiley \& Sons, Inc.: Hoboken, NY, USA, 2002.

31. Baik, S.; Kim, S.G.; Lee, J.; Lee, J.I. Study on $\mathrm{CO}_{2}$-water printed circuit heat exchanger performance operating under various $\mathrm{CO}_{2}$ phases for $\mathrm{S}-\mathrm{CO}_{2}$ power cycle application. Appl. Therm. Eng. 2017, 113, 1536-1546. [CrossRef]

32. Ahn, Y.H.; Kim, M.S.; Lee, J.I. S- $\mathrm{CO}_{2}$ cycle design and control strategy for the SFR application. In Proceedings of the 5th International Symposium-Supercritical $\mathrm{CO}_{2}$ Power Cycles, San Antonio, TX, USA, 28-31 March 2016.

(C) 2019 by the authors. Licensee MDPI, Basel, Switzerland. This article is an open access article distributed under the terms and conditions of the Creative Commons Attribution (CC BY) license (http://creativecommons.org/licenses/by/4.0/). 